\title{
Vegetation change across the Drake Passage region linked to late Eocene cooling and glacial disturbance after the Eocene-Oligocene Transition
}

5 Nick Thompson ${ }^{1}$, Ulrich Salzmann ${ }^{1}$, Adrián López-Quirós ${ }^{2,3}$, Peter K. Bij1 ${ }^{4}$, Frida S. Hoem ${ }^{4}$, Johan Etourneau $^{3}$, Marie-Alexandrine Sicre ${ }^{5}$, Sabine Roignant ${ }^{6}$, Emma Hocking ${ }^{1}$, Michael Amoo ${ }^{1}$, Carlota Escutia $^{3}$

${ }^{1}$ Department of Geography and Environmental Sciences, Northumbria University, Newcastle upon Tyne, UK.

${ }^{2}$ Department of Geoscience, Aarhus University, Høegh-Guldbergs Gade 2, 8000, Aarhus C, Denmark.

$10 \quad{ }^{3}$ Instituto Andaluz de Ciencias de la Tierra, CSIC-Universidad de Granada, Granada, Spain.

${ }^{4}$ Department of Earth Sciences, Utrecht University, Utrecht, The Netherlands.

${ }^{5}$ Sorbonne Universites (UPMC, Univ. Paris 06)-CNRS-IRD-MNHN, LOCEAN Laboratory, Paris, France.

${ }^{6}$ Institut Universitaire Europeen de la Mer, Plouzane, France.

Correspondence to: Nick Thompson (alasdair.thompson@northumbria.ac.uk)

15 Abstract. The role and climatic impact of the opening of the Drake Passage and how it affected both marine and terrestrial environments across the Eocene-Oligocene Transition (EOT $\sim 34 \mathrm{Ma}$ ) period remains poorly understood. Here we present new terrestrial palynomorph data compared with recently compiled lipid biomarker ( $n$-alkane) data from Ocean Drilling Program (ODP) Leg 113 Site 696 drilled on the margin of the South Orkney Microcontinent in the Weddell Sea, to investigate changes in terrestrial environments and paleoclimate across the late Eocene and early Oligocene ( 37.6-32.2 Ma). Early late Eocene

20 floras and sporomorph-based climate estimates reveal Nothofagus-dominated forests growing under wet temperate conditions, with mean annual temperature (MAT) and precipitation (MAP) around $13^{\circ} \mathrm{C}$ and $1660 \mathrm{~mm}$, respectively. A phase of latest Eocene terrestrial cooling at $35.5 \mathrm{Ma}$ reveals a decrease in MAT by around $2{ }^{\circ} \mathrm{C}$ possibly linked to the opening of the Powell Basin. This is followed by an increase in Mesozoic sporomorphs together with a shift in terrestrial biomarkers and sedimentological evidence indicating ice expansion to coastal and shelf areas approximately 34.1 million years ago. However, major changes to the terrestrial vegetation at Site 696 did not take place until the early Oligocene, where there is a distinct expansion of gymnosperms and cryptogams accompanied by a rapid increase in taxa diversity following 33.5 Ma. This unusual expansion of gymnosperms and cryptogams is suggested to be linked to environmental disturbance caused by repeat glacial expansion and retreat, which facilitated the expansion of conifer and ferns. We conclude that the timing of glacial onset rather suggests that the event at site 696 is linked to the global cooling at the EOT and that latest Eocene regional cooling cannot

30 directly be linked. Therefore, confirming that the opening of ocean gateways alone did not trigger Antarctic glaciation, even if ocean gateways may have played a role in stepwise cooling before the EOT. 


\section{Introduction}

The Cenozoic progression from greenhouse to icehouse climate conditions was accompanied by the establishment of the Antarctic ice sheet around the Eocene-Oligocene Transition (EOT 34.44-33.65 Ma; e.g., Hutchinson et al., 2021). This change in Earth climate state is evidenced by a prominent excursion in oxygen isotope ratios from marine biogenic calcite (e.g., Zachos et al., 2001, 2008; Westerhold et al., 2020) during the Earliest Oligocene Oxygen Isotope Step (EOIS 33.65Ma; Hutchinson et al., 2021). The possible causes of the onset of Antarctic glaciation are poorly understood and ambiguity remains as to whether a single or combination of factors and feedbacks drove the Cenozoic climate transition (e.g., DeConto and Pollard, 2003; Coxall and Pearson, 2007). Uncertainties particularly remain over the role of the opening and deepening of the Drake

40 Passage on the development of the Antarctic Circumpolar Current (ACC), and how this affected both marine and terrestrial environments (Scher and Martin, 2008; Houben et al., 2019). Today the ocean currents and the ACC exerts a strong influence on the Earth's climate system, playing an important role in the global distribution of heat, nutrients, salt, carbon, as well as in the gas exchange between the atmosphere and the ocean. Given that unabated anthropogenic warming is expected to cause a poleward shift of the ACC and potentially weaken thermohaline circulation (Zhang and Delworth, 2005) this study forms part of a wider need to fully understand the Earth climate system in order to better predict future stability of the Antarctic ice sheet.

A major obstacle in understanding the role of the opening Drake Passage and ocean currents in Cenozoic climate change has been the lack of well dated continuous records spanning the EOT from the region. Here we present new terrestrial palynomorph data from Ocean Drilling Program (ODP) Leg 113 Site 696 Hole B (herein referred to as Site 696), containing a well recovered EOT section, depicting changes in terrestrial environments and paleoclimate from the late Eocene to early Oligocene $(\sim 37.6-$ 32.2 Ma; Houben e al., 2013, 2019). Vegetation composition, structure and diversity patterns are reconstructed along with sporomorph-based quantitative climate estimates in order to explore the timing and nature of vegetation and climate change across the northern Antarctic Peninsula region and South Orkney Microcontinent (SOM). The results are compared with recently compiled lipid biomarker ( -alkane) data (López-Quirós et al., in review), and dinoflagellate cyst data (Houben et al.,

55 2013) to better understand shifts in marine as well as terrestrial environments and the source of terrestrial versus aquatic organic matter. Our results reveal a possible link between changing oceanographic conditions and latest Eocene terrestrial cooling around 35.5 Ma, before glacial onset in the region.

\section{Materials and Methods}

60 Site 696, hole B was drilled on the south-eastern margin of the SOM (Fig.1; latitude: $61^{\circ} 50.959^{\prime} \mathrm{S}$, longitude: $42^{\circ} 55.996^{\prime} \mathrm{W}$ ) at 650m water depth, as part of ODP Leg 113 in 1987 (Barker et al., 1988). The recovered section consists of late Eocene to Quaternary hemipelagic (214-0 mbsf), diatomaceous (530-214 mbsf), and terrigenous (645.4-530 mbsf) sediments (Barker et al., 1988; Wei and Wise, 1990; Gersonde and Burckle, 1990; López-Quirós et al., 2019, 2020, in review) and is divided into 
seven lithological units (I-VII), primarily based on composition and diagenetic maturity of sediments (Fig. 2; Barker et al., 1988). This study focuses on pollen and spores recovered from the terrigenous unit VII (cores 113-696B-62R through 113696B-53R; Fig. 2). Age-control based primarily on the presence of calcareous nannofossils (Wei and Wise, 1990 sensu Villa et al., 2008; and a revised dinoflagellate cysts age model (Houben et al., 2013, 2019), places the studied section at 33.2 to 37.6 Ma (Table 1), with sediments encompassing the EOT and EOIS event well recovered between $571.5 \mathrm{mbsf}$ to $569.1 \mathrm{mbsf}$ (Houben et al., 2013).

A total of 35 samples from the late-middle Eocene to earliest Oligocene (643.73-520.88 mbsf) were analysed for their pollen and spore content. Raw data collected is available from the PANGEA database (Thompson et al., awaiting validation). All palynological slides were prepared using standard chemical palynological processing techniques following the protocols at the University of Northumbria, Department of Geography and Environmental Sciences and the Laboratory of Palaeobotany and 75 the Laboratory of Palaeobotany and Palynology of Utrecht University. Slides were analysed using a Leica DM500 and Leica DM2000 transmitted light microscopes at 200x and 1000x magnification. Where possible, counts of 300 (excluding reworked grains) sporomorphs were made. Only samples containing 50 or more in situ sporomorphs were used for further analysis and evaluation.

80 Identification and taxonomic classification of sporomorphs were carried out primarily following Cookson (1950), Cookson and Pike (1954), Dettmann et al. (1990), Dettmann and Jarzen (1996), Truswell and Macphail (2009) and Raine et al. (2011). Botanic and taxonomic affinities used to identify the Nearest Living Relatives (NLR) of fossil species were established mainly after Truswell and Macphail (2009) and Raine et al. (2011) and references therein (Table 2.). Identification of reworked grains are mainly based on the age-restriction of the species, with species older than Eocene or Oligocene (e.g., Mesozoic species)

85 being easily recognised as reworked. Consideration was also given to whether a grain was reworked based on the level of thermal maturity and its state of preservation. All palynomorphs identified as in situ are regarded as being penecontemporaneous with deposition and are included in the final calculation of sporomorph percentages. Pollen percentages were plotted using riojaPlot, based on the R package rioja (Juggins, 2020) and local zones were established using the CONISS (Constrained Incremental Sum-of-Squares: Grimm, 1987) cluster analysis function. Sporomorph diversity was measured using

90 both the Shannon-Wiener index and the observed number of taxa. A rarefaction method for sums of $\geq 50$ and $\geq 100$ grains was applied, so that the effect caused by differences in the sample size may be removed allowing the estimation of the number of sporomorph species at a constant sample size (Raup, 1975; Birks and Line, 1992). The Shannon-Wiener Index was also carried out as the second measure of sporomorph diversity accounting for species richness and evenness (Shannon, 1948; Magurran, 2013; Morris et al., 2014). Samples containing less than 50 grains were omitted from this analysis. Detrended Correspondence

95 Analysis (DCA) was performed, with downweighting of rare species by removing pollen types whose representation is $<5 \%$. This ordination technique is used in order to evaluate ecological patterns within the data, using knowledge of the distribution of NLR and their modern environmental gradients (Correa-Metrio, 2014). Rarefaction, Shannon-Wiener and DCA were all 
https://doi.org/10.5194/cp-2021-84

Preprint. Discussion started: 16 July 2021

(c) Author(s) 2021. CC BY 4.0 License.

(c) (i)

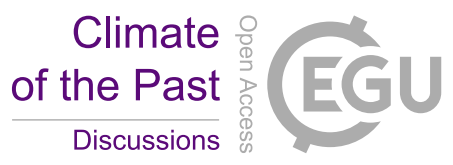

performed using the software R for statistical computing (R Development Core Team, 2013) and the package Vegan (Oksanen et al., 2013).

\subsection{Bioclimatic Analysis}

Estimates for terrestrial mean annual temperature (MAT), mean annual precipitation (MAP), warmest month mean temperature (WMMT) and coldest month mean temperature (CMMT) were obtained using the NLR approach in conjunction with the Probability Density Function (PDF) method. Fossil taxa used and their NLR are shown in Table 2.

105 Climate estimates based on the NLR approach use presence or absence data and are independent of the relative abundance of individual taxa. This makes this method ideal for sporomorph based climate estimates from marine sediments, where hydrodynamic sorting of grains may cause variations in the percentages of individual taxa (Arias, 2015), and also helps reduce taphonomic biases (Klages et al., 2020). However, the assumption that modern species and their climate requirements are an analogy for the geological past is one of the biggest weaknesses of the NLR approach. This uncertainty inevitably increases the further back in the geological record (Hollis et al., 2019). It should also be noted that the modern distribution of species may be a function of either its past climate or biogeographic history (Reichgelt et al., 2016; Willard et al., 2019). Nevertheless, temperature estimates derived from the NLR approach are often in agreement with those from other botanical methods and geochemical proxies, providing a certain level of confidence (Klages et al., 2020; Pross et al. 2012).

115 The PDF method is used to statistically constrain the most likely climate co-occurrence window for an assemblage (Harbert and Nixon, 2015; Willard et al., 2019; Klages et al., 2020). The bioclimatic envelope for each NLR was identified by cross plotting the modern distribution from the Global Biodiversity Information Facility (GBIF; GBIF, 2021) with the gridded WorldCLIM (Fick and Hijmans, 2017) climate surface data using the dismo package (Hijmans et al., 2017) in R. Some taxa were grouped at the family level because of their potentially ambiguous climatic affinity. This includes (1) taxa belonging to the genus Nothofagus, a group that is one of the most abundant in the Antarctic fossil record, due to the ambiguous climatic affinity of the subgenus Brassospora, now endemic to New Caledonia; (2) pollen taxa affiliated with the modern-day genus Microcachrys, of which Microcachrys tetragona is the sole species, on the basis that M. tetragona is only found in specific location in Tasmania under narrow climatic and environmental conditions which are likely not representative of this once widespread genus; and (3) the pollen taxa Peninsulapollis gillii, which has links to the modern genus Beauprea now also endemic to New Caledonia. In these cases, Nothofagaceae, Podocarpaceae and Proteaceae were used, respectively, rather than the genus or species as the NLR.

\subsection{Geochemical analyses}

The following section will focus on the interpretation of lipid biomarker ( $n$-alkane) and stable isotope data from Site 696. For a full description of geochemical methods see López-Quirós et al., in review. 
https://doi.org/10.5194/cp-2021-84

Preprint. Discussion started: 16 July 2021

(c) Author(s) 2021. CC BY 4.0 License.

(c) (i)

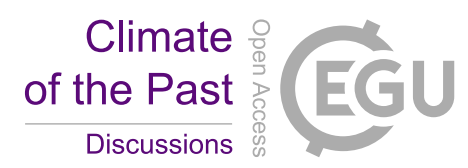

\section{$130 \quad$ 2.3.1 Lipid biomarkers ( $n$-alkanes)}

The distribution of $n$-alkanes in sediments can be assessed on the basis of carbon chain length in order to determine potential biological sources (Cranwell, 1973; Rieley et al., 1991; Bi et al., 2005; Duncan et al., 2019; López-Quirós et al., in review). Algae and bacteria typically produce shorter chain lengths $\left(\mathrm{C}_{12}-\mathrm{C}_{22}\right.$; Clark and Blumer, 1967; Han and Calvin, 1969; Cranwell et al., 1987; Grimalt and Albaigés, 1987; Duncan et al., 2019), while aquatic plants and Sphagnum mosses are characterised

135 by enhanced production of $\mathrm{C}_{23}$ to $\mathrm{C}_{25}$ chain lengths (Baas et al., 2000; Ficken et al., 2000; Pancost et al., 2002; Bingham et al., 2010; Duncan et al., 2019). Long chain $n$-alkanes ( $\mathrm{C}_{25}$ and higher) are most abundantly produced by terrestrial higher plants (Eglinton and Hamilton, 1963; Duncan et al., 2019). Therefore, medium to long chain $n$-alkane $\left(\mathrm{C}_{23}-\mathrm{C}_{31}\right)$ distributions can provide details about the origin of organic matter in sediments, differentiating between terrigenous and marine, providing information about palaeovegetation and palaeoclimate (Meyers et al., 1997; Ficken et al., 2000; Schefuß et al., 2003; Vogts et

140 al., 2009; Duncan et al., 2019; López-Quirós et al., in review).

(a) ACL (Average Chain Length $n$-alkane index)

The ACL index indicates the dominant $n$-alkane in a given carbon number range (Poynter et al., 1989; Schefuß et al., 2003;

145 Duncan et al., 2019) and is calculated following Eq. (1):

$\mathrm{ACL}=\frac{\Sigma\left[\mathrm{C}_{\mathrm{i}}\right] \cdot i}{\Sigma\left[\mathrm{C}_{\mathrm{i}}\right]}$,

$\mathrm{C} i=$ carbon number of the odd chain length $n$-alkanes (i.e., from $n-\mathrm{C}_{25}$ to $n$ - $\mathrm{C}_{31}$ ).

$i=$ concentration of the odd $n$-alkanes.

150 Variations in the ACL index through time can be used as a proxy of terrestrial organic matter inputs and can also provide information on changes in climate (Collister et al., 1994; Rommerskirchen et al., 2006; Mahiques et al., 2017; Duncan et al., 2019; López-Quirós et al., in review). Plants produce higher ACLs in warmer, tropical regions, whilst lower ACLs are generally observed from cooler climates (Poynter et al., 1989; Sicre and Peltzer, 2004; Jeng, 2006; Vogts et al., 2009; Bush and McInerney, 2015; Duncan et al., 2019; López-Quirós et al., in review). Studies have also suggested plants synthesise longer $n$-alkanes in more arid environments providing plants with a more efficient wax coating to restrict water loss (e.g., Kolattukudy et al., 1976; Schefuß et al., 2003; Calvo et al., 2004; Zhou et al., 2005; Moossen et al., 2015; Jalali et al., 2017, 2018), indicating aridity has a strong control on ACL and that ACL index values decrease under wetter conditions (Duncan et al., 2019; López-Quirós et al., in review).

(b) $\mathrm{P}_{\text {aq }}$ (Aquatic Plant $n$-alkane index) 
The $\mathrm{P}_{\mathrm{aq}}$ index provides an approximate measure of the relative sedimentary contribution of submerged and floating aquatic macrophytes relative to emergent and terrestrial vegetation (Ficken et al., 2000; López-Quirós et al., in review) and is calculated following Eq. (2):

$165 \mathrm{P}_{a q}=\frac{\mathrm{C}_{23}+\mathrm{C}_{25}}{\mathrm{C}_{23}+\mathrm{C}_{25}+\mathrm{C}_{29}+\mathrm{C}_{31}}$,

where relationships between n-alkane indices were studied using Pearson's correlation coefficients and assesses as statistically significant when $\mathrm{p}<0.05$.

Sphagnum mosses also have a molecular distribution similar to submerged and floating macrophytes, showing enhanced production of $\mathrm{C}_{23}$ and/or $\mathrm{C}_{25}$ (Baas et al., 2000; Nott et al. 2000; Nichols et al., 2006; Duncan et al., 2019). Therefore, the $\mathrm{P}_{\text {aq }}$ index reflects the input from Sphagnum and aquatic plants versus terrestrial vegetation. At Site $696 \mathrm{P}_{\text {aq }}$ values $<0.23$ indicate a dominance of terrestrial plant waxes, while higher values of 0.48 to 0.49 imply an enhanced contribution of enhanced submerged and floating, and/or Sphagnum moss (López-Quirós et al., in review).

(c) TI (Terrestrial $n$-alkanes index)

The TI index is based on the assumption that inputs from photosynthetic algae and bacteria are characterised by short-chain $n$ alkanes (C12-C22; Clark and Blumer, 1967; Han and Calvin, 1969; Cranwell et al., 1987; Grimalt and Albaigés, 1987; Duncan et al., 2019) compared to higher land plants rich in $\mathrm{C}_{27}, \mathrm{C}_{29}$ and $\mathrm{C}_{31}$ (Bourbonniere and Meyers, 1996; Mahiques et al., 2017; López-Quirós et al., in review). The TI index is calculated as a ratio over the Total Organic Carbon (TOC; Mahiques et al., 2017) following Eq. (3):

$\mathrm{TI}=\frac{\Sigma \mathrm{C}_{27+29+31}}{\mathrm{TOC}}$,

This parameter therefore assumes that higher values of TI characterize a greater input of terrestrial plant-derived organic matter (Mahiques et al., 2017; López-Quirós et al., in review).

\section{2.3.2 TOC (Total Organic Carbon)}

TOC represents the organic fraction preserved in sediments and can be used to help distinguish between marine and terrestrial sources of organic matter, depositional conditions and organic matter production (Calvert and Pedersen, 1993; Meyers and Ishiwatari, 1993; Avramidis et al., 2014, 2015). Organic matter in marine sediments is mainly derived from the decomposition of plants, animals and most importantly plankton (Avramidis et al., 2015). High planktonic primary production and

190 zooplankton grazing causing an increased export of organic matter through the water column to the sea floor support increased preservation of organic carbon in sediments. Therefore, TOC may be used as an indicator for palaeoproductivity even though 
https://doi.org/10.5194/cp-2021-84

Preprint. Discussion started: 16 July 2021

(c) Author(s) 2021. CC BY 4.0 License.

(c) (i)

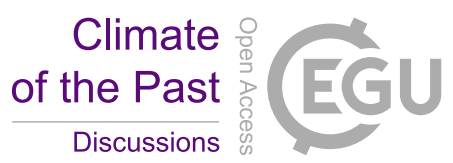

it also depends on degradation and thus the residence time in the water column (Sarnthein et al. 1988; Lyle et al. 1988; Berger and Herguera 1992; Freudenthal et al. 2002; Jahn et al. 2003; Luo et al., 2013; Frihmat et al., 2015). Coastal sediments with a shorter water column contain higher amounts of TOC than open sea sediments. Organic carbon burial is also affected by redox conditions, and terrigenous detrital matter influx also exert a control and should be taken into account when interpreting TOC in terms of palaeoproductivity (Luo et al., 2013). At Site 696 increased levels of TOC coincide with higher abundance of heterotrophic dinoflagellate cysts (Houben et al., 2013) and may be used to support the notion of high marine palaeoproductivity.

\section{Results}

200 The recovery of palynomorphs is good throughout the section. Of the 34 samples analysed 5 do not contain a sufficient amount of sporomorphs and were discarded from further analysis. In total 74 pollen taxa (58 angiosperms and 16 gymnosperms), 24 spores and 1 sporomorph of unknown affiliation were identified (excluding reworked and unidentified sporomorphs), containing 54 genera. The stratigraphic distribution and relative abundance of major taxa groups is shown in Fig. 3. Major pollen and spore taxa, in order of decreasing abundance, include Nothofagidites spp., Podocarpidites spp., undifferentiated

205 bisaccates, Cyathidites spp., Phyllocladidites spp. and Retitriletes, which occur commonly throughout the Eocene and Oligocene sections.

Based on the results of CONISS ordination the succession is divided into 2 main zones (I and II; Fig. 3). In addition, Zone I is further subdivided ( $\mathrm{Ia} \mathrm{Ib}$ ), based on the abundance and frequency of taxa. The results of rarefaction and DCA analysis along with the diversity indices results also show a good distinction between Zones I and II.

\subsection{Zone I, 37.6-33.6 Ma (643.73-568.82 mbsf)}

Zone I comprises of 18 samples (62R 6W 142-144 to 55R 1W 62-64). Based on the age models of Wei and Wise (1990) and Houben et al. $(2013,2019)$ and linear extrapolation, the lowermost 16 samples are placed in the Eocene, while the uppermost 2 samples are placed into the earliest Oligocene (37.6 Ma to $\sim 33.6 \mathrm{Ma}$ ). Quantitatively, Zone I is typified by relatively low

215 numbers of sporomorph species and low diversity. Based on rarefaction analysis, the average number of sporomorph species per sample is $13.28 \pm 1.05$ (mean $\pm \mathrm{SD}$ ) at a count of 50 specimens. Low levels of diversity are confirmed by the Shannon diversity indices $(\mathrm{H})$, which indicates an average of $1.79 \pm 0.06$.

The overall Zone I assemblage is dominated by the southern beech, Nothofagus (pollen taxa: Nothofagidites). On average Nothofagidites pollen accounts for $79.0 \%$ of all non-reworked taxa and $95.0 \%$ of all angiosperm taxa. Taxa belonging to the Nothofagidites lachlaniae complex (subgenus: Fuscospora) are the most abundant followed by undifferentiated Nothofagus spp. sporomorphs and taxa belonging to the $N$. rocanensis/saraensis complex (subgenus: Nothofagus). Other angiosperm pollen (non-Nothofagidites) is rare, making up about $4.2 \%$ of the non-reworked sporomorph assemblage in Zone 1 . Of the 
https://doi.org/10.5194/cp-2021-84

Preprint. Discussion started: 16 July 2021

(c) Author(s) 2021. CC BY 4.0 License.

\section{(c) (i)}

non-Nothofagus angiosperm taxa the most abundantly occurring, in order of decreasing abundance, include Proteacidites

(NLR: Proteaceae), Tricolpites (Dicotyledonae), Liliacidites intermedius (Liliaceae) and Lateropora glabra (Freycinetia).

Other less common angiosperms are typically only represented by one or two occurrences. The second most abundant group are the gymnosperms, which account for $10.6 \%$ of all non-reworked taxa. Predominantly gymnosperms are represented by the pollen taxa (in order of abundance) Podocarpidites, Phyllocladidites, Trichotomosulcites subgranulatus (all Podocarpaceae) and Araucariacites australis (Araucariaceae). Undifferentiated bisaccate grains also make up a large portion of the gymnosperms observed in Zone I. Many of these are likely to belong to Podocarpidites however folding of the grains has made further identification impossible. Cryptogams account for $6.23 \%$ of non-reworked taxa in Zone 1 and include both ferns and mosses. Abundantly occurring cryptogam spores include taxa belonging to the Retitriletes/Lycopodiacidites spp. complex (Lycopodiaceae), Cyathidites (Cyatheaceae), Ischyosporites gremius (Filicopsida) and Coptospora archangelskyi (Conostomum).

The Subzone Ia assemblage is unique in that Arecipites spp. (Arecaceae), Beaupreaidites (Beauprea), Myrtaceidites cf. mesonesus (Myrtaceae) and Dacrydiumites florinii/praecupressinoides (Dacrydium), all warmth loving taxa whose NLRs predominantly have a tropical and subtropical distribution, especially in the Pacific, Southeast Asia and New Caledonia, and only occur in this subzone. Ericipites cf. scabratus (Ericaceae), Chenopodipollis cf. chenopodiaceoides (Chenopodiaceae), Polypodiisporites cf. radiatus (Davallia) and Podosporites (Podocarpaceae) are also unique to Subzone Ia of Zone I. In addition, taxa belonging to the Nothofagidites asperus complex (subgenus: Lophozonia), Microcachryidites antarcticus, Trichotomosulcites subgranulatus (both Podocarpaceae), Gleicheniidites (Gleicheniaceae) and Ischyosporites (Filicopsida) are more abundant than the rest of Zone I. Whereas, Coptospora (Conostomum) and Liliacidites are less abundant than the remainder of Zone I. Of the entire studied section, Proteacidites cf. Scabratriporites greatly increase in abundance and frequency from Subzone Ib. Other rare taxa also only occur in Subzone Ia or Ib of Zone I but are represented by one or two specimens. Sporomorph-based climate reconstructions reveal significantly higher temperatures within Subzone Ia compared to Subzone Ib, with an interval of latest Eocene cooling occurring around $35.5 \mathrm{Ma}$. MAT ranges from $10.9^{\circ} \mathrm{C}$ to $16.6^{\circ} \mathrm{C}$ and MAP ranges from $1418 \mathrm{~mm}$ to around $1850 \mathrm{~mm}$, with an average of $12.8^{\circ} \mathrm{C}$ and $1661 \mathrm{~mm}$ respectively for Subzone Ia. For Subzone Ib MAT ranges from $10.3^{\circ} \mathrm{C}$ to $11.4^{\circ} \mathrm{C}$ and MAP is between $1362 \mathrm{~mm}$ and $1858 \mathrm{~mm}$, with an average of $10.8^{\circ} \mathrm{C}$ and $1591 \mathrm{~mm}$ respectively (Fig. 4).

\subsection{Zone II, ca. 33.5-32.2 Ma (563.38-549.70 mbsf)}

The 11 samples of Zone II (53R 1W 80-82 to 54R 3W 38-41) are assigned an Oligocene age. Zone II records a strong increase in gymnosperms and cryptogams, accompanied by a rapid rise in taxa diversity between ca. 33.5 and 32 Ma and a contemporaneous increase in reworked Mesozoic sporomorphs (Fig. 3). Based on the results of rarefaction analysis the average number of sporomorph species for a count size of 50 individuals is $19.63 \pm 2.00$. The results of the Shannon diversity index are between 1.97 and 2.12, with an average of $2.06 \pm 0.05$. 
The Zone II sporomorph assemblage shows a significant decrease in Nothofagus compared to Zone I. Nothofagus pollen make up $51.2 \%$ of all non-reworked taxa and $89.9 \%$ of all angiosperm taxa in Zone II. Pollen taxa belonging to the Nothofagidites lachlaniae complex (subgenus: Fuscospora) remain the most abundant, followed by taxa belonging to the $N$. rocanensis/saraensis complex (subgenus: Nothofagus), with undifferentiated Nothofagidites spp. sporomorphs close behind. However, other Nothofagus taxa are less abundant. Although a slight increase in other angiosperms (non-Nothofagus) occurs in Zone II they remain the smallest botanical group, representing just 5.8\% of all non-reworked sporomorphs. In order of abundance, from least to most abundant, significant non-Nothofagus angiosperm taxa include Proteacidites, Tricolpites, Myricipites harrisii (Casuarinaceae) and Peninsulapollis gillii (Proteaceae). Additional angiosperm taxa are typically represented by one or two occurrences. Gymnosperms remain the second most abundant botanical group, but their abundance has increased strongly, representing $28.3 \%$ of all non-reworked sporomorphs in Zone II. The gymnosperm assemblage remains dominated by Podocarpidites and Phyllocladidites, which are the two most common gymnosperm taxa respectively. However, other changes in the gymnosperm pollen assemblage are taking place with Dilwynites (Wollemia) particularly increasing in frequency and abundance, along with Alisporites cf. australis (Gymnospermopsida), Microcachryidites antarcticus, Podosporites and Trichotomosulcites subgranulatus (all Podocarpaceae), among others. Undifferentiated bisaccate grains, that likely belong to Podocarpidites, also continue make up a large proportion of the assemblage but are unable to be properly identified. Sporomorph-based climate estimates provide no evidence for abrupt cooling at the Eocene/Oligocene boundary. Within the early Oligocene Zone II MATs are between $\sim 10.3^{\circ} \mathrm{C}$ to $13.7^{\circ} \mathrm{C}$ and MAP ranges from $1423 \mathrm{~mm}$ to $1860 \mathrm{~mm}$ a year, with an average of $11.5^{\circ} \mathrm{C}$ and $1626 \mathrm{~mm}$ respectively (Fig. 4). These results indicate a slight increase in both temperature and precipitation compared to the latest Eocene Subzone Ib.

\section{Discussion}

\subsection{Sediment Transport and Provenance}

The late Eocene terrestrial vegetation assemblage from Site 696 shares a number of similarities with Antarctic Peninsula palaeofloras of similar ages (e.g., Warny and Askin 2011b; Warny et al., 2019). Both Site 696 and Antarctic Peninsula late Eocene assemblages are dominated by Nothofagidites pollen, predominantly those related to the modern subgenus Fuscospora, with secondary gymnosperms including high frequencies of podocarp conifer pollen. Similar angiosperm and cryptogam assemblages are also seen between the two, with angiosperms such as Proteaceae and Liliaceae and cryptogams such as Cyatheaceae and Sphagnum. This finding may therefore suggest that pollen from the Antarctic Peninsula region could have been transported to the SOM during this time. Furthermore, similarities between nearby Seymour Island sediments, both in composition and paleogeographic setting, suggest a related source, and that the SOM was proximal enough to receive some detritus from the Antarctic Peninsula (Barker et al., 1988; López-Quirós et al., in review). However, despite these similarities' significant differences in the palaeoflora occurs between the two regions indicating the Antarctic Peninsula may not have been 
https://doi.org/10.5194/cp-2021-84

Preprint. Discussion started: 16 July 2021

(c) Author(s) 2021. CC BY 4.0 License.

(c) (i)

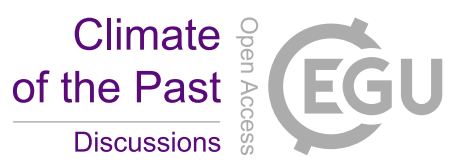

the primary sediment source. In agreement with previous observations by Mohr (1990) the sporomorph assemblage from Site 696 contains a greater diversity of angiosperm pollen compared to late Eocene Antarctic Peninsula palaeofloras (e.g., Anderson et al., 2011; Warny and Askin 2011b; Warny et al., 2019). This higher diversity has also been reported in southern South American Paleogene sporomorph floras (e.g., Romero and Zamaloa, 1985; Romero and Castro, 1986). In addition, the late Eocene Zone Ia assemblage (37.6-35.5 Ma) contains the paratropical taxa and warmth loving taxa Arecipites spp. (Arecaceae), Myrtaceidites cf. mesonesus (Myrtaceae), Dacrydiumites florinii/praecupressinoides (Dacrydium) and Polypodiisporites cf. radiatus (Davallia) not recorded in coeval Antarctic Peninsula assemblages, possibly due to the more northern latitude of the SOM resulting in milder climatic conditions. In addition, the occurrence of moderate to well-preserved in situ benthic foraminifera, with predominantly angular to subangular terrigenous particles, does not support the notion of long-distance transport of sediments from adjacent sources (e.g., Seymour Island; López-Quirós et al., in review). These observations, together with an expansion of gymnosperm conifers and cryptogams recorded during the early Oligocene (33.5-32.2 Ma) at Site 696, but absent from Antarctic Peninsula floras (e.g., Askin et al., 1992; Anderson et al., 2011), suggest that the vegetation of the SOM was unique in character and that a significant proportion of detrital material was likely of local origin (e.g., exposed parts of the SOM).

Furthermore, the SOM and the northern Antarctic Peninsula underwent significant rifting during the late Eocene and early Oligocene ( 37-30 Ma; King and Barker, 1988; Eagles and Livermore, 2002; van de Lagemaat et al., 2021), forming what would become the Powell Basin (Eagles and Livermore, 2002; Eagles and Jokat, 2014; van de Lagemaat et al., 2021; LópezQuirós et al., in review). Throughout the latest Eocene ( $\sim 35.5-34.1 \mathrm{Ma})$, a decrease in the delivery of coarse terrigenous sediments and a drop in sedimentation rates by almost half is observed as the SOM became more distal from the Antarctic Peninsula due to the opening of the proto-Powell Basin (Eagles and Livermore, 2002; López-Quirós et al., in review). Deposition of moderately to intensely bioturbated silty mudstones across the EOT ( 34.1-33.6Ma) indicate continued subsidence-related marine transgression at Site 696 (López-Quirós et al., in review). This subsequent and continued isolation of the SOM would have caused Site 696 to receive a greater proportion of localised sediments from exposed parts of the SOM. This supports the results of this study that the majority of sediments supplied to Site 696 at this time were of local origin, perhaps still with some contribution from the northern Antarctic Peninsula.

Conversely however, Carter et al. (2017) suggested the majority of the late Eocene ( $36.5-33.6 \mathrm{Ma})$ sediments deposited at Site 696 are not of local origin. Using detrital zircon U-Pb and apatite thermochronometry analysis these authors concluded that sand grains from the late Eocene Site 696 best matched sources within the Ellsworth-Whitmore Mountains in West Antarctica and that sediments therefore must have been transported to the SOM by ice. However, the presence of in situ 320 paratropical taxa within the early-late Eocene of Site 696 (37.6-35.5 Ma) suggests mild and even ice-free conditions during this overlapping time period. Furthermore, palaeo-sea-surface temperature reconstructions (Douglas et al., 2014; Hoem and Bijl, unpublished) indicate relatively warm conditions $\left(\sim 14^{\circ} \mathrm{C}\right)$, and fossil dinoflagellate cyst (Houben et al., 2013, 2019), 
https://doi.org/10.5194/cp-2021-84

Preprint. Discussion started: 16 July 2021

(c) Author(s) 2021. CC BY 4.0 License.

\section{(c) (i)}

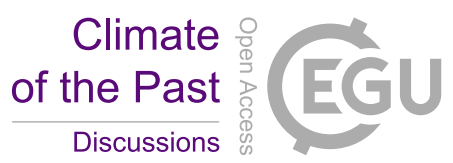

calcareous nannofossils (Wei and Wise, 1990) and smectite-dominated clay mineralogy (Fig. 2: Robert and Maillot, 1990) support temperate depositional conditions (López-Quirós et al., in review) not favourable for transport by ice. Sediments deposited within two coarse-grained mudstone intervals within a fine-grained transgressive sequence are likely sourced from coastal/shelf areas of the SOM (López-Quirós et al., in review), attesting to the continued supply of detritus from the SOM. Therefore, these results and those of this study indicate that transportation by ice was unlikely and that a majority of sediments transported to Site 696 are likely of local origin from exposed parts of the SOM.

\subsection{Palaeoenvironment}

\subsubsection{Late Eocene Palaeoenvironment}

Sediments from Site 696 record two distinct palaeofloras from the late Eocene Zone I to the early Oligocene Zone II assemblage that evolved in response to an increase in environmental disturbance beginning around 34.1 Ma. Throughout the Zone I assemblage ( 37.6-33.6 Ma) abundant Nothofagus with secondary Podocarpaceae, minor angiosperm and cryptogam elements indicate the presence of a relatively humid Nothofagus-dominated temperate rainforest, growing under MATs between $\sim 10.3^{\circ} \mathrm{C}$ and $16.6^{\circ} \mathrm{C}$, and MAP of $1362 \mathrm{~mm}$ and $1858 \mathrm{~mm}$ (Fig. 4). Comparison with lipid biomarker $n$-alkane results

(Fig. 5.; López-Quirós et al., in review) indicates ACL indicative of temperate vegetation, supporting this interpretation. In addition, marine palynomorphs (Houben et al., 2013) and calcareous nannofossil (Wei and Wise, 1990) assemblages attest to temperate marine depositional conditions further suggesting temperate conditions prevailed during this time. Nothofagus (predominantly Fuscospora-type), together with less common Podocarpaceae, formed the forest canopy across much of the mid- to higher-altitude areas, with tracts perhaps dominated by one or the other due to natural differences in shade tolerance (Poole, 1987; Veblen et al., 1996; Gallagher et al., 2008; Bowman et al., 2014). Microcachrys along with Araucariaceae, Ericaceae, Liliaceae, Chenopodiaceae and low growing proteaceous shrubs, also reflect better drained higher-altitude habitats as well as coastal and marginal forest environments (Kühl et al., 2002; MacPhail et al., 1999; Kershaw and Wagstaff, 2001; Bowman et al., 2014). Today, similar cool temperate Nothofagus-dominated mixed-podocarp forests occur in the temperate 345 Valdivian region of southern Chile, between $37^{\circ} 45^{\prime}$ and 4320'S (Veblen et al., 1983, 1996; Poole et al., 2001, 2003; Cantrill and Poole, 2012a; Bowman et al., 2014) across elevations greater than 2000m to lowland areas (Kershaw, 1988; Punyasena et al., 2011; Arias, 2015), where westerly trade winds from the Pacific result in high precipitation.

Pollen taxa representing vegetation communities with very different temperature requirements exist within the early-late Eocene ( 35.5-37.6 Ma) Subzone Ia. The presence of the paratropical taxa Arecaceae (palms), Beauprea, Myrtaceae and Dacrydium, each occurring intermittently throughout thus subzone (643.73-597.66 mbsf), indicates the existence of a temperate-paratropical vegetation community. These communities are not recorded in coeval Antarctic Peninsula assemblages perhaps due to the Antarctic peninsulas high mountainous palaeotopography (Wilson et al., 2012) and/or the lower latitude of the SOM. Paratropical taxa likely occupied sheltered lowland areas and favourable coastal margins and would have required 
https://doi.org/10.5194/cp-2021-84

Preprint. Discussion started: 16 July 2021

(c) Author(s) 2021. CC BY 4.0 License.

mild temperatures and the absence of winter frosts, owing to the frost sensitivity of extant palms (Larcher and Winter, 1981, Tomlinson, 2006, Eiserhardt et al., 2011, Reichgelt et al., 2018). Sporomorph based climate estimates reveal Coldest Month Mean Temperatures (CMMT) between $7.5^{\circ} \mathrm{C}$ and $13.5^{\circ} \mathrm{C}$, well above freezing (Fig. 4). In addition, warmth-loving ferns including Gleicheniaceae and rare Davalliaceae also occur together with moisture-loving conifers such as Dacrydium, which only occur in Subzone Ia, and Phyllocladus, further indicating warm wet temperate conditions throughout this subzone. Today these taxa occur in subtropical to temperate regions in lowland sheltered environments, often thriving in wet humid conditions and severely disturbed or pioneer habitats at the margins of rainforests and waterways (Specht et al., 1992; Chinnock and Bell, 1998; Bowman et al., 2014; Arias, 2015).

The co-occurrence of prominent vegetation communities, each with very different temperature and moisture requirements therefore suggests that late Eocene forests across the northern Antarctic Peninsula and SOM were subject to climatic gradients related to differences in elevation and proximity to the coastline. Furthermore, the presence of paratropical and warm taxa within Subzone Ia and the lack of cold temperature taxa reveal conditions were warmer, by around $2{ }^{\circ} \mathrm{C}$ between 37.6 and 35.5 $\mathrm{Ma}$, compared to the rest of Zone I and the early Oligocene Zone II, indicating a phase of latest Eocene cooling from 35.5 to $35 \mathrm{Ma}$. The cooling between 35.5 and $35 \mathrm{Ma}$ recorded by the terrestrial palynomorph assemblage coincides with a slight decrease in the terrestrial $n$-alkanes Index (TI; Mahiques et al., 2017), which records absolute input of $n$ - $\mathrm{C}_{27}+{ }_{29}+30$-rich molecules present in vascular plants, indicating decreased input of terrestrial plant-derived organic matter (Fig. 5; LópezQuirós et al., in review). The latest Eocene cooling recorded at Site 696 after 35.5 Ma corresponds with large-scale changes in vegetation composition and decreasing diversity from Antarctic Peninsula palaeoflora records (e.g., Askin, 2000; Anderson et al., 2011; Warny and Askin, 2011a, 2011b). Furthermore, an upwards-increase in illite clay minerals (Robert and Maillot,

375 1990) between approximately 36.4 to $33.9 \mathrm{Ma}$, signifying a shift in weathering regime from chemical to physical, supports the idea of latest Eocene climate cooling.

An initial spike in reworked Mesozoic sporomorphs at around 34.1 Ma at the onset of the EOT indicates an increase in reworking. This coincides with increasing Eocene dinoflagellate cyst taxa percentages over Protoperidiniaceae (Houben et al.,

380 2013). Sediments within this EOT interval also exhibit two coarsening-upward packages, within an otherwise fine-grained sequence. Furthermore, these sedimentary packages contain the first evidence for ice-rafted debris (IRDs; Barker et al., 1988; López-Quirós et al., in review) in conjunction with a high percentage of illite clay minerals (Robert and Maillot, 1990). Based on these observations, significant ice build-up around the northern Antarctic Peninsula and SOM is inferred, with a period of continental ice expansion to the coast or beyond (López-Quirós et al., in review). This is supported by the presence of glacial

385 surface textures on sand grains (Kirshner and Anderson, 2011) and rare drop stones (Wellner et al., 2011) from late Eocene (34-37 Ma; Bohaty et al., 2011) sediments offshore James Ross Basin, as well as other sedimentological and geochemical evidence indicating late Eocene and early Oligocene cooling and ice expansion on the northern Antarctic Peninsula (e.g., Robert and Maillot, 1990; Ivany et al., 2008). Furthermore, topographic reconstructions indicate the northern Antarctic 
https://doi.org/10.5194/cp-2021-84

Preprint. Discussion started: 16 July 2021

(c) Author(s) 2021. CC BY 4.0 License.

Peninsula at the EOT was comparable in elevation to the Trans Antarctic Mountains and Dronning Maud Land (Wilson et al.,

2012). In model simulations these are suggested nucleation points for late Eocene and Oligocene glaciation (DeConto and Pollard 2003; DeConto et al., 2007), suggesting a glacial presence in the Antarctic Peninsula region is reasonable during this time (Carter et al., 2017; Lepp, 2018). However, the pollen and spore assemblage from site 696 as well as other late Eocene and Oligocene sporomorph assemblages from the Antarctic Peninsula (e.g., Anderson et al., 2011; Askin and Warny 2011a), indicate the region still retained some vegetation and therefore was never fully glaciated.

\subsubsection{Early Oligocene Palaeoenvironment}

Despite the evidence for a cooling of terrestrial climate between 35.5 Ma and 35 Ma, and latest Eocene glacial onset around 34.1 Ma the terrestrial palynomorph assemblage from Site 696 indicates that Nothofagus-dominated forests did not change dramatically in composition until the early Oligocene, after the EOIS. An expansion of conifer trees and cryptogams accompanied by a rapid increase in taxa diversity is recorded between approximately 33.5 and $32 \mathrm{Ma}$. This significant transformation of Antarctic flora in the early Oligocene is quantitatively reflected by the results of DCA analysis, as well as by a decrease in $n$-alkane ACL, which in turn suggest herbaceous plants and/or conifer dominance (Fig. 5; López-Quirós et al., in review). The diversity patterns derived from the Shannon diversity index and rarefaction analysis show that early Oligocene forests contained a significantly higher number of taxa compared with the late Eocene forest communities. Previous studies (e.g., Cantrill, 2001; Rain and Askin, 2001; Prebble et al., 2006; Griener and Warny, 2015) suggest that significant cooling and drying of the climate across the EOT led to decreasing diversity and a lowering of the forest canopy, with low stature forests formed of scrubby dwarf Nothofagus and podocarps in sheltered regions and low altitude coastal zones. However, based on the relatively high diversity and frequency of cryptogam taxa and non-Nothofagus angiosperms within the Zone II assemblage, these Nothofagus-podocarp forests would have been at least intermediate in stature and relatively open, allowing the development of fern, shrub and bryophyte communities (e.g., Macphail and Truswell, 2004). When compared to $n$-alkane results an increase in the abundance of cryptogams, specifically Sphagnum moss, is also supported by an increase in the aquatic plant $n$-alkane index $\left(\mathrm{P}_{\mathrm{aq}}\right)$ and $n-\mathrm{C}_{23} / n-\mathrm{C}_{29}$ ratios throughout the early Oligocene (López-Quirós et al., in review).

Within the early Oligocene ( 33.5-32.2 Ma) Zone II assemblage, the increase in Coptospora and Stereisporites (Sphagnum), along with some angiosperms such as Liliacidites and possibly Myricipites, suggest the progression towards colder environments. Coptospora and Liliacidites have been found in Oligocene and Miocene assemblages across Antarctica, including the Ross Sea region (e.g., Askin and Rain, 2000; Prebble et al., 2006), Meyer Desert Formation (e.g., Lewis et al., 2008), Wilkes Land (e.g., Sangiorgi et al., 2018) and the Antarctic Peninsula (e.g., Warny and Askin 2011a). These Oligocene/Miocene assemblages have been inferred to represent tundra mosaic vegetation in cold, possibly glacial, landscapes (Francis and Hill, 1996; Macphail and Truswell, 2004; Prebble et al., 2006). In addition, the presence of common millimetre

420 sized IRDs between approximately 564 and 560 mbsf suggests phases of continental ice expansion to coastal and possibly shelf areas (Barker et al., 1988; López-Quirós et al., in review). Within this same interval sporomorph-based climate 
reconstructions also reveal a cooling and drying step, with a decrease in MAT and MAP from around $13.4^{\circ} \mathrm{C}$ to $10.7^{\circ} \mathrm{C}$ and $1815 \mathrm{~mm}$ to $1423 \mathrm{~mm}$, between $\sim 33.5 \mathrm{Ma}$ and $33.4 \mathrm{Ma}$. The initially relatively high temperatures during the earliest Oligocene may be associated with the reported return to near-Eocene climate soon after the EOT (Liu et al., 2009; Houben et al., 2012; Wilson et al., 2013) and is possibly also reflected in a shift in some organic matter indices across the EOT and after the EOIS (Fig. 5; López-Quirós et al., in review). However, further interpretation of this sediment section is hampered by a gap in core recovery. The increase in typical tundra taxa together with common IRD indicates a potential phase of cooling and glacial expansion during the earliest Oligocene, possibly punctuated by the development of milder climates (e.g., Liu et al., 2009; Houben et al., 2012; Wilson et al., 2013).

Warming and cooling phases with episodes of ice growth and retreat would have caused environmental disturbance, likely reducing the extent of Nothofagus-dominated forested areas that were established throughout the Eocene. In New Zealand today Nothofagus seedlings are able to capitalise more readily on small canopy openings enabling them to out-compete podocarps in old-growth stands (Lusk et al., 2015). However, unlike podocarps juvenile Nothofagus also require shelter from

435 frost and desiccation, finding it hard to establish themselves amongst other vegetation in open and marginal forest environments until this other vegetation has been partially suppressed through overtopping by Nothofagus (Wardle, 1964; Lusk et al., 2015 Rawlence et al., 2020). Thus, conifers are probably favoured by exogenous disturbance, providing a shortlived reprieve from angiosperm competition (Enright \& Hill 1995; Lusk et al., 2015). Across the EOT and earliest Oligocene glacial related environmental disturbance and the development of milder climates, possibly after the EOT (e.g., Liu et al., 2009; Houben et al., 2012; Wilson et al., 2013), would have therefore facilitated the expansion of different vegetation types previously suppressed by the dominance of Nothofagus, due to the limited dispersal ability of Nothofagus. Furthermore, a study by Galeotti et al. (2016), suggested that until ca. 32.2 Ma any Antarctic ice sheet would have been extremely sensitive to orbitally paced, local insolation forcing and would have be prone to large fluctuations. Variability in ice volume during the early Oligocene are also reflected by greatly varying benthic $\delta^{18} \mathrm{O}$ confirming large fluxes in Antarctic ice during this time.

445 Therefore, the unusual expansion of gymnosperms and cryptogams seen at Site 696 is suggested to be related to an increase in environmental disturbance caused by repeated glacial expansion and retreat, with the first major glacial expansion around 34.1 Ma, together with the competitive dominance of podocarps on exposed disturbed sites (Fig. 6). A lack of evidence for marine reworking after the EOT and good agreement between terrestrial biomarkers (LópezQuirós et al., in review) and the fossil sporomorph record suggest that the changes in the terrestrial palynomorph 450 assemblage during the early Oligocene $(\sim 33.5 \mathrm{Ma})$ reflect true climate signals and increased environmental disturbance caused by glacial onset. Moreover, the results of this study reveal that major changes in terrestrial vegetation took place after the onset of glaciation rather than after terrestrial climate cooling that took place during the latest Eocene after 35.5Ma. 
https://doi.org/10.5194/cp-2021-84

Preprint. Discussion started: 16 July 2021

(c) Author(s) 2021. CC BY 4.0 License.

(c) (i)

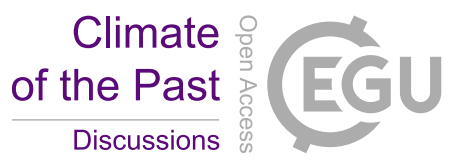

\subsection{Paleoceanography}

455

460

Importantly these change in oceanographic conditions associated with the opening of the Powell Basin occur synchronously with terrestrial cooling at $35.5 \mathrm{Ma}$, within the resolution of this study. Furthermore, large-scale changes in vegetation composition and decreasing diversity from Antarctic Peninsula (e.g., Askin, 2000; Anderson et al., 2011; Warny and Askin, 2011a, 2011b) also occur at this time. Therefore, this may suggest a link between marine and terrestrial environments and that the opening of the Powell Basin and the establishment of oceanic upwelling may have driven a large-scale regional cooling step at 35.5 Ma. However, the regional change in oceanography and marine environments cannot be directly linked with the 485 terrestrial vegetation change and glacial onset in the region, that took place about one million years later, at 34.1 Ma. The timing of the second cooling rather suggest that the event at site 696 is linked to the global cooling at the onset of the EOT 
which is documented by a combination of deep-ocean cooling and global ice sheet growth marking the step from a largely ice-free greenhouse world to an icehouse climate (Hutchinson et al. 2020).

\section{Conclusion}

The terrestrial palynomorph assemblage from ODP Site 696 in the Weddell Sea records two distinct palaeofloras that evolved in response to increased environmental disturbance and provide insight into late Eocene and early Oligocene terrestrial climate and cryosphere evolution. Late Eocene pollen and spore assemblages reveal a terrestrial climate cooling at 35.5 Ma with a decrease in MAT by an average of $2^{\circ} \mathrm{C}$, associated with a shift from temperate-paratropical Nothofagus-dominated forests to cool temperate Nothofagus-dominated forests. This cooling of terrestrial climate after 35.5 Ma coincides with changes in floral diversity and composition in palaeoflora records from the Antarctic Peninsula (e.g., Askin, 2000; Anderson et al., 2011; Warny and Askin, 2011a, 2011b), which have been interpreted to reflect the onset of prolonged cooling in the region. Despite evidence for terrestrial cooling and ice expansion, Nothofagus-dominated forests did not change dramatically in composition until the early Oligocene, when there was distinct expansion of gymnosperms and cryptogams accompanied by a rapid increase in taxa diversity between approximately 33.5 and $32 \mathrm{Ma}$. We suggest that glacial related environmental disturbance, starting around 34.1 Ma, reflected by an increase in cold climate taxa and sedimentological evidence for ice transport and erosion (e.g., Robert and Maillot, 1990; López-Quirós et al., 2019, in review), facilitated the expansion of different vegetation types previously suppressed by the dominance of Nothofagus.

505 The cooling step at 35.5 Ma coincides with an abrupt change to marine environments at Site 696, indicated by the appearance of mature glaucony-bearing facies ( 588.8 to 577.9 mbsf; López-Quirós et al., 2019). Development of this glauconitic section has been related to the opening of the Powell Basin, resulting in decreased sedimentation rates and the development of oceanic upwelling fuelling high marine biological productivity and the development suboxic bottom waters (López-Quirós et al., 2019, in review). The coincidence between terrestrial cooling and changes to ocean currents and marine environments at Site 696 possibly indicates a strong link between ocean and terrestrial environmental change, suggesting the opening of the Powell Basin and reorganisation of ocean currents triggered a regional cooling step at 35.5 Ma prior to glacial onset at 34.1 Ma. However, the large temporal gap ( 1.4 Ma) between oceanographic changes and glacial onset suggests that the opening of ocean gateways did not alone trigger glaciation, even if ocean gateways may have played a role in stepwise cooling. 
https://doi.org/10.5194/cp-2021-84

Preprint. Discussion started: 16 July 2021

(c) Author(s) 2021. CC BY 4.0 License.

(c) (i)

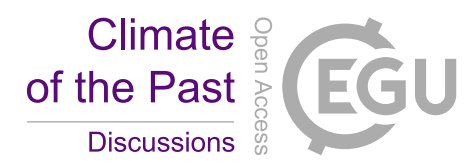

\section{Data Availability}

515 All data will be available on the www.pangaea.de database (submitted 02/07/2021, awaiting validation)

\section{Acknowledgments}

NT received funding from the Natural Environment Research Council (NERC)-funded Doctoral Training Partnership ONE Planet [NE/S007512/1]. Funding for this research was also provided by the Spanish Ministry of Science and Innovation (grants CTM2014-60451-C2-1/2-P and CTM2017-89711-C2-1/2-P) cofounded by the European Union through FEDER funds. This work used Deep Sea Drilling Project archived samples provided by the International Ocean Discovery Program (IODP). We thank the staff at the Gulf Coast core repository (GCR) for assistance in ODP Leg 113 core handling and shipping. We thank CNRS for the salary support of MAS.

\section{Author contributions}

525 NT and US designed the research and NT analysed pollen and spores. ALQ added sedimentological and geochemical analyses. NT prepared the manuscript with contribution from all co-authors.

\section{References}

Anderson, J. B., Warny, S., Askin, R. A., Wellner, J. S., Bohaty, S. M., Kirshner, A. E., Livsey, D. N., Simms, A. R., Smith, T. R., Ehrmann, W., Lawver, L. A., Barbeau, D., Wise, S. W., Kulhanek, D. K., Weaver, F. M., and Majewski, W.: Progressive Cenozoic cooling and the demise of Antarctica's last refugium, Proc. Natl. Acad. Sci., 108, 11356-11360, https://doi.org/10.1073/pnas.1014885108, 2011.

Arias, L. C.: Terrestrial ecosystems on a Greenhouse Earth: Climate and vegetation in the high southern latitudes during the early Paleogene, Ph.D. thesis, Faculty of Geosciences and Geography, Johann Wolfgang Goethe University Frankfurt am Main, Germany, 2015.

Askin, R. A. and Raine, J. I.: Oligocene and Early Miocene terrestrial palynology of the Cape Roberts Drillhole CRP-2/2A, Victoria Land Basin, Antarctica, Terra Antart., 7(4), 493-501, 2000.

Askin, R. A.: Spores and Pollen from the Mcmurdo Sound Erratics, Antarctica, in: Paleobiology and Paleoenvironments of Eocene Rocks: McMurdo Sound, East Antarctica, 76, edited by: Stilwell, J. D., Feldmann, R. M., American Geophysical Union, United States, 161-181, https://doi.org/10.1029/AR076p0161, 2000.

540 Avramidis, P., Iliopoulos, G., Panagiotaras, D., Papoulis, D., Lambropoulou, P., Kontopoulos, N., Siavalas, G., and Christanis, K.: Tracking Mid- to Late Holocene depositional environments by applying sedimentological, palaeontological and geochemical proxies, Amvrakikos coastal lagoon sediments, Western Greece, Mediterranean Sea, Quat. Int., 332, 1936, https:// doi.org/10.1016/j.quaint.2013.09.006, 2014. 
Avramidis, P., Nikolaou, K., and Bekiari, V.: Total Organic Carbon and Total Nitrogen in Sediments and Soils: A Comparison of the Wet Oxidation - Titration Method with the Combustion-infrared Method, Agric. Agric. Sci. Procedia, 4, 425430, https://doi.org/10.1016/j.aaspro.2015.03.048, 2015.

Baas, M., Pancost, R., van Geel, B., and Sinninghe Damsté, J. S.: A comparative study of lipids in Sphagnum species, Org. Geochem., 31, 535-541, https://doi.org/10.1016/S0146-6380(00)00037-1, 2000.

Banerjee, S., Bansal, U., Pande, K., and Meena, S. S.: Compositional variability of glauconites within the Upper Cretaceous Karai Shale Formation, Cauvery Basin, India: implications for evaluation of stratigraphic condensation, Sediment. Geol., 331, 12-29, https://doi.org/10.1016/j.sedgeo.2015.10.012, 2016.

Barker, P.F., Kennett, J.P. and Shipboard Scientific Party.: Leg 113, in: Proceedings of the Ocean Drilling Program Initial Reports of Leg 113, 607-704, https//doi.org/10.29.73/odp.proc.ir.113.1900, 1988.

Basak, C. and Martin, E. E.: Antarctic weathering and carbonate compensation at the Eocene-Oligocene transition, Nat. Geosci., 6(2), 121-124, https://doi.org/10.1038/ngeo1707, 2013.

Berger, W. H. and Herguera, J. C.: Reading the Sedimentary Record of the Ocean's Productivity BT- Primary Productivity and Biogeochemical Cycles in the Sea, edited by: Falkowski, P. G., Woodhead, A. D., and Vivirito, K., Springer US, Boston, MA, 455-486, https://doi.org/10.1007/978-1-4899-0762-2_24, 1992.

Bi, X., Sheng, G., Liu, X., Li, C., and Fu, J.: Molecular and carbon and hydrogen isotopic composition of n-alkanes in plant leaf waxes, Org. Geochem., 36(10), 1405-1417, https://doi.org/10.1016/j.orggeochem.2005.06.001, 2005.

Bingham, E. M., McClymont, E. L., Väliranta, M., Mauquoy, D., Roberts, Z., Chambers, F. M., Pancost, R. D., and Evershed, R. P.: Conservative composition of n-alkane biomarkers in Sphagnum species: Implications for palaeoclimate reconstruction in ombrotrophic peat bogs, Org. Geochem., 41(2), 214-220, https://doi.org/10.1016/j.orggeochem.2009.06.010, 2010.

Birks, H. J. B. and Line, J. M.: The use of Rarefaction Analysis for Estimating Palynological Richness from Quaternary PollenAnalytical Data, 2(1), 1-10, https://doi.org/10.1177/095968369200200101, 1992.

Bohaty, S. M., Kulhanek, D. K., Wise Jr., S. W., Jemison, K., Warny, S., and Sjunneskog, C.: Age Assessment of EocenePliocene Drill Cores Recovered During the SHALDRIL II Expedition, Antarctic Peninsula, https://doi.org/10.1029/2010SP001049, 1 January 2011.

Bourbonniere, R. A. and Meyers, P. A.: Characterization of sedimentary humic matter by alkaline hydrolysis, Org. Geochem., 5(3), 131-142, https://doi.org/https://doi.org/10.1016/0146-6380(83)90023-2, 1983.

Bowman, V. C., Francis, J. E., Askin, R. A., Riding, J. B., and Swindles, G. T.: Latest Cretaceous-earliest Paleogene vegetation and climate change at the high southern latitudes: palynological evidence from Seymour Island, Antarctic Peninsula, Palaeogeogr. Palaeoclimatol. Palaeoecol., 408, 26-47, https://doi.org/10.1016/j.palaeo.2014.04.018, 2014.

575 Bush, R. T. and McInerney, F. A.: Leaf wax n-alkane distributions in and across modern plants: Implications for paleoecology and chemotaxonomy, Geochim. Cosmochim. Acta, 117, 161-179, https://doi.org/10.1016/j.gca.2013.04.016, 2013. 
https://doi.org/10.5194/cp-2021-84

Preprint. Discussion started: 16 July 2021

(c) Author(s) 2021. CC BY 4.0 License.

(c) (i)

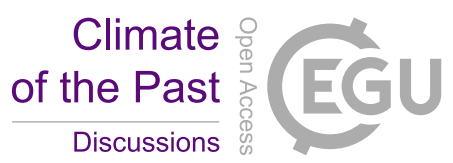

Bush, R. T. and McInerney, F. A.: Influence of temperature and C4 abundance on n-alkane chain length distributions across the central USA, Org. Geochem., 79, 65-73, https://doi.org/10.1016/j.orggeochem.2014.12.003, 2015.

Calvert, S. E. and Pedersen, T. F.: Geochemistry of Recent oxic and anoxic marine sediments: Implications for the geological record, Mar. Geol., 113(1), 67-88, https://doi.org/10.1016/0025-3227(93)90150-T, 1993.

Calvo, E., Pelejero, C., Logan, G. A., and De Deckker, P.: Dust-induced changes in phytoplankton composition in the Tasman Sea during the last four glacial cycles, Paleoceanography, 19(2), https://doi.org/10.1029/2003PA000992, 2004.

Cantrill, D. J.: Early Oligocene Nothofagus from CRP-3, Antarctica: Implications for the vegetation history, Terra Antart., 8(4), 401-406, 2001.

Cantrill, D. J. and Poole, I.: After the heat: late Eocene to Pliocene climatic cooling and modification of the Antarctic vegetation, in: The Vegetation of Antarctica through Geological Time, edited by Cantrill, D. J. and Poole, I., Cambridge University Press, Cambridge, 390-457, https://doi.org/DOI: 10.1017/CBO9781139024990.009, 2012b.

Cantrill, D. J. and Poole, I.: The heat is on: Paleogene floras and the Paleocene-Eocene warm period, in: The Vegetation of Antarctica through Geological Time, edited by: Cantrill, D. J. and Poole, I., Cambridge University Press, Cambridge, 308-389, https://doi.org/DOI: 10.1017/CBO9781139024990.008, 2012a.

Carter, A., Riley, T. R., Hillenbrand, C.-D., and Rittner, M.: Widespread Antarctic glaciation during the Late Eocene, Earth Planet. Sci. Lett., 458, 49-57, https://doi.org/10.1016/j.eps1.2016.10.045, 2017.

Chinnock, R. J. and Bell, G. H.: Gleicheniaceae, flora of Australia Online, 1998.

Clark R. C., J. and Blumer, M.: Distribution of n-paraffins in marine organisms and sediment 1, Limnol. Oceanogr., 12, 7987, https://doi.org/10.4319/lo.1967.12.1.0079, 1967.

Collister, J. W., Rieley, G., Stern, B., Eglinton, G., and Fry, B.: Compound-specific $\delta 13 \mathrm{C}$ analyses of leaf lipids from plants with differing carbon dioxide metabolisms, Org. Geochem., 21(6), 619-627, https://doi.org/10.1016/01466380(94)90008-6, 1994.

Cook, P. J. and Marshall, J. F.: Geochemistry of iron and phosphorus-rich nodules from the east Australian continental shelf, Mar. Geol., 41(3-4), 205-221, https://doi.org/10.1016/0025-3227(81)90081-51981.

Cookson, I.: Fossil pollen grains of proteaceous type from Tertiary deposits in Australia, Aust. J. Biol. Sci., 3(2), 166-177, https://doi.org/10.1071/BI9500166, 1950.

Cookson, I. C. and Pike, K. M.: Some dicotyledonous pollen types from Cainozoic deposits in the Australian region, Aust. J. Bot., 2(2), 197-219, https://doi.org/10.1071/BT9540197, 1954.

605 Correa-Metrio, A., Dechnik, Y., Lozano-García, S., and Caballero, M.: Detrended correspondence analysis: A useful tool to quantify ecological changes from fossil data sets, Boletín la Soc. Geológica Mex., 66(1), 135-143, 2014.

Coxall, H. K. and Pearson, P. N.: The Eocene-Oligocene transition, Deep Time Perspect. Clim. Chang. Marrying Signal From Comput. Model. Biol. Proxies, 351-387, https://doi.org/10.1144/TMS002.16, 2007.

Cranwell, P. A.: Chain-length distribution of n-alkanes from lake sediments in relation to post-glacial environmental change, Freshw. Biol., 3(3), 259-265, https://doi.org/10.1111/j.1365-2427.1973.tb00921.x, 1973. 
https://doi.org/10.5194/cp-2021-84

Preprint. Discussion started: 16 July 2021

(c) Author(s) 2021. CC BY 4.0 License.

Cranwell, P. A., Eglinton, G., and Robinson, N.: Lipids of aquatic organisms as potential contributors to lacustrine sedimentsII, Org. Geochem., 11, 513-527, https://doi.org/10.1016/0146-6380(87)90007-6, 1987.

DeConto, R. M. and Pollard, D.: Rapid Cenozoic glaciation of Antarctica induced by declining atmospheric CO 2, Nature, 421(6920), 245-249, https://doi.org/10.1038/nature01290, 2003.

DeConto, R., Pollard, D., and Harwood, D.: Sea ice feedback and Cenozoic evolution of Antarctic climate and ice sheets, Paleoceanography, 22(3), https://doi.org/10.1029/2006PA001350, 2007.

Dettmann, M. E., Pocknall, D. T., Romero, E. J., and Zamaloa, M. del C.: Nothofagidites Erdtman ex Potonié, 1960; a catalogue of species with notes on the paleogeographic distribution of Nothofagus Bl.(Southern Beech), New Zeal. Geol. Surv. Paleontol. Bull., 1990.

Dettmann, M. E. and Jarzen, D. M.: Pollen of proteaceous-type from latest Cretaceous sediments, southeastern Australia, 20(2), 103-160, https://doi.org/10.1080/03115519608619193, 1996.

Diekmann, B., Kuhn, G., Gersonde, R., and Mackensen, A.: Middle Eocene to early Miocene environmental changes in the sub-Antarctic Southern Ocean: evidence from biogenic and terrigenous depositional patterns at ODP Site 1090, Glob. Planet. Change, 40(3-4), 295-313, https://doi.org/10.1016/j.gloplacha.2003.09.001, 2004.

Dodson, J. R.: Modern pollen spectra from Chatham Island, New Zealand, New Zeal. J. Bot., 14 (4), 341-347, https://doi.org/10.1080/0028825X.1976.10428907, 1976.

Douglas, P. M. J., Affek, H. P., Ivany, L. C., Houben, A. J. P., Sijp, W. P., Sluijs, A., Schouten, S., and Pagani, M.: Pronounced zonal heterogeneity in Eocene southern high-latitude sea surface temperatures, 111(18), 6582-6587, https://doi.org/10.1073/pnas.1321441111, 2014.

Duncan, B., McKay, R., Bendle, J., Naish, T., Inglis, G. N., Moossen, H., Levy, R., Ventura, G. T., Lewis, A., and Chamberlain, B.: Lipid biomarker distributions in Oligocene and Miocene sediments from the Ross Sea region, Antarctica: Implications for use of biomarker proxies in glacially-influenced settings, Palaeogeogr. Palaeoclimatol. Palaeoecol., 516, 71-89, https://doi.org/10.1016/j.palaeo.2018.11.028, 2019.

Eagles, G. and Jokat, W.: Tectonic reconstructions for paleobathymetry in Drake Passage, 611, 28-50, https://doi.org/10.1016/j.tecto.2013.11.021, 2014.

Eagles, G. and Livermore, R. A.: Opening history of Powell Basin, Antarctic Peninsula, Mar. Geol., 185(3-4), 195-205, https://doi.org/10.1016/S0025-3227(02)00191-3, 2002.

Eiserhardt, W. L., Svenning, J.-C., Kissling, W. D., and Balslev, H.: Geographical ecology of the palms (Arecaceae): determinants of diversity and distributions across spatial scales, Ann. Bot., 108, 1391-1416, https://doi.org/10.1093/aob/mcr146, 2011.

El Frihmat, Y., Hebbeln, D., Jaaidi, E. L. B., and Mhammdi, N.: Reconstruction of productivity signal and deep-water conditions in Moroccan Atlantic margin $\left(\sim 35^{\circ} \mathrm{N}\right)$ from the last glacial to the Holocene, Springerplus, 4(1), 69, https://doi.org/10.1186/s40064-015-0853-6, 2015. 
https://doi.org/10.5194/cp-2021-84

Preprint. Discussion started: 16 July 2021

(c) Author(s) 2021. CC BY 4.0 License.

Elliot, D. H.: Tectonic setting and evolution of the James Ross Basin, northern Antarctic Peninsula, in: Geology and Paleontology of Seymour Island, Antarctic Peninsula, edited by: Feldmann, R. M., and Woodburne, M. O., Geological Society of America, Memoir no. 16, Boulder, Colorado, 541-555, 1988.

Enright, N.J. and Hill, R.S. (Eds): Ecology of the southern conifers, Melbourne University Press, Carlton, Australia, 1995.

Feakins, S. J., Peters, T., Wu, M. S., Shenkin, A., Salinas, N., Girardin, C. A. J., Bentley, L. P., Blonder, B., Enquist, B. J., Martin, R. E., Asner, G. P., and Malhi, Y.: Production of leaf wax n-alkanes across a tropical forest elevation transect, Org. Geochem., 100, 89-100, https://doi.org/10.1016/j.orggeochem.2016.07.004, 2016.

Fick, S. E. and Hijmans, R. J.: WorldClim 2: new 1-km spatial resolution climate surfaces for global land areas, Int. J. Climatol., 37(12), 4302-4315, https://doi.org/10.1002/joc.5086, 2017.

Ficken, K. J., Li, B., Swain, D. L., and Eglinton, G.: An n-alkane proxy for the sedimentary input of submerged/floating freshwater aquatic macrophytes, Org. Geochem., 31(7), 745-749, https://doi.org/10.1016/S0146-6380(00)00081-4, 2000.

Francis, J. E. and Hill, R. S.: Fossil plants from the Pliocene Sirius Group, Transantarctic Mountains; evidence for climate from growth rings and fossil leaves, Palaios, 11(4), 389-396, https://doi.org/10.2307/3515248, 1996.

Freudenthal, T., Meggers, H., Henderiks, J., Kuhlmann, H., Moreno, A., and Wefer, G.: Upwelling intensity and filament activity off Morocco during the last 250,000 years, Deep Sea Res. Part II Top. Stud. Oceanogr., 49(17), 3655-3674, https://doi.org/10.1016/S0967-0645(02)00101-7, 2002.

Galeotti, S., DeConto, R., Naish, T., Stocchi, P., Florindo, F., Pagani, M., Barrett, P., Bohaty, S. M., Lanci, L., Pollard, D., Sandroni, S., Talarico, F. M., and Zachos, J. C.: Antarctic Ice Sheet variability across the Eocene-Oligocene boundary climate transition, Science, 352(6281), 76 LP - 80, https://doi.org/10.1126/science.aab0669, 2016.

Gallagher, S. J., Wagstaff, B. E., Baird, J. G., Wallace, M. W., and Li, C. L.: Southern high latitude climate variability in the Late Cretaceous greenhouse world, Glob. Planet. Change, 60(3), 351-364, https://doi.org/10.1016/j.gloplacha.2007.04.001, 2008.

GBIF: GBIF Occurrence Download [data set], https://doi.org/10.15468/dl.te8pxs, 2021.

Gersonde, R., Burckle, L.H.: Neogene Diatom biostratigraphy of ODP Leg 113, Weddell Sea Antarctic Ocean. In: Barker, P.F., Kennett J.P., et al., Proceeding of the Ocean Drilling Program, Scientific Results, Leg 113, 113, 761-789, 1990.

Griener, K. W. and Warny, S.: Nothofagus pollen grain size as a proxy for long-term climate change: An applied study on Eocene, Oligocene, and Miocene sediments from Antarctica, Rev. Palaeobot. Palynol., 221, 138-143, https://doi.org/10.1016/j.revpalbo.2015.06.003, 2015.

Grimalt, J. and Albaigés, J.: Sources and occurrence of C12 C22n-alkane distributions with even carbon-number preference in sedimentary environments, Geochim. Cosmochim. Acta, 51(6), 1379-1384, https://doi.org/10.1016/00167037(87)90322-X, 1987.

Grimm, E. C.: CONISS: a FORTRAN 77 program for stratigraphically constrained cluster analysis by the method of incremental sum of squares, Comput. Geosci., 13(1), 13-35, https://doi.org/10.1016/0098-3004(87)90022-7, 1987. 
https://doi.org/10.5194/cp-2021-84

Preprint. Discussion started: 16 July 2021

(c) Author(s) 2021. CC BY 4.0 License.

\section{(c) (i)}

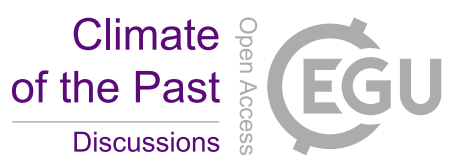

Han, J. and Calvin, M.: HYDROCARBON DISTRIBUTION OF ALGAE AND BACTERIA, AND MICROBIOLOGICAL ACTIVITY IN SEDIMENTS, Proc. Natl. Acad. Sci., 64(2), 436 LP - 443, https://doi.org/10.1073/pnas.64.2.436, 1969.

Harbert, R. S. and Nixon, K. C.: Climate reconstruction analysis using coexistence likelihood estimation (CRACLE): A method for the estimation of climate using vegetation, Am. J. Bot., 102(8), 1277-1289, https://doi.org/10.3732/ajb.1400500, 2015.

Hijmans, R. J., Phillips, S., Leathwick, J., and Elith, J.: Species distribution modeling with R, R Packag. version 0.8-11, cran [code], http://cran.r-project.org/web/packages/dismo/index.html, 2013.

Hollis, C. J., Dunkley Jones, T., Anagnostou, E., Bijl, P. K., Cramwinckel, M. J., Cui, Y., Dickens, G. R., Edgar, K. M., Eley, Y., and Evans, D.: The DeepMIP contribution to PMIP4: methodologies for selection, compilation and analysis of latest Paleocene and early Eocene climate proxy data, incorporating version 0.1 of the DeepMIP database, Geosci. Model Dev., 12(7), 3149-3206, https://doi.org/10.5194/gmd-12-3149-2019, 2019.

690 Houben, A. J. P.: Triggers and consequences of glacial expansion across the Eocene-Oligocene Transition, Ph.D. thesis, Department of Earth Sciences, Utrecht University, Utrecht, Netherlands, 2012.

Houben, A. J. P., Bijl, P. K., Pross, J., Bohaty, S. M., Passchier, S., Stickley, C. E., Röhl, U., Sugisaki, S., Tauxe, L., van de Flierdt, T., Olney, M., Sangiorgi, F., Sluijs, A., Escutia, C., and Brinkhuis, H.: Reorganization of Southern Ocean Plankton Ecosystem at the Onset of Antarctic Glaciation, Science, 340(6130), 341 LP - 344, https://doi.org/10.1126/science.1223646, 2013.

Houben, A. J. P., Bijl, P. K., Sluijs, A., Schouten, S., and Brinkhuis, H.: Late Eocene Southern Ocean Cooling and Invigoration of Circulation Preconditioned Antarctica for Full-Scale Glaciation, Geochemistry, Geophys. Geosystems, 20(5), 2214-2234, https://doi.org/10.1029/2019GC008182, 2019.

Hutchinson, D. K., Coxall, H. K., Lunt, D. J., Steinthorsdottir, M., de Boer, A. M., Baatsen, M., von der Heydt, A., Huber, M., Kennedy-Asser, A. T., and Kunzmann, L.: The Eocene-Oligocene transition: a review of marine and terrestrial proxy data, models and model-data comparisons, Clim. Past, 17, 269-315, https://doi.org/10.5194/cp-17-269-2021, 2021.

Ivany, L. C., Van Simaeys, S., Domack, E. W., and Samson, S. D.: Evidence for an earliest Oligocene ice sheet on the Antarctic Peninsula, Geology, 34(5), 377-380, https://doi.org/10.1130/G22383.1, 2006.

Ivany, L. C., Lohmann, K. C., Hasiuk, F., Blake, D. B., Glass, A., Aronson, R. B., and Moody, R. M.: Eocene climate record of a high southern latitude continental shelf: Seymour Island, Antarctica, GSA Bull., 120(5-6), 659-678, https://doi.org/10.1130/B26269.1, 2008.

Jahn, B., Donner, B., Müller, P. J., Röhl, U., Schneider, R. R., and Wefer, G.: Pleistocene variations in dust input and marine productivity in the northern Benguela Current: Evidence of evolution of global glacial-interglacial cycles, Palaeogeogr. Palaeoclimatol. Palaeoecol., 193(3), 515-533, https://doi.org/10.1016/S0031-0182(03)00264-5, 2003. 
https://doi.org/10.5194/cp-2021-84

Preprint. Discussion started: 16 July 2021

(c) Author(s) 2021. CC BY 4.0 License.

(c) (i)

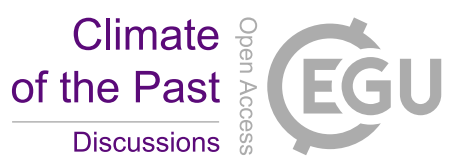

Jalali, B., Sicre, M.-A., Kallel, N., Azuara, J., Combourieu-Nebout, N., Bassetti, M.-A., and Klein, V.: High-resolution Holocene climate and hydrological variability from two major Mediterranean deltas (Nile and Rhone), The Holocene, 27(8), 1158-1168, https://doi.org/10.1177/0959683616683258, 2017.

Jalali, B., Sicre, M.-A., Klein, V., Schmidt, S., Maselli, V., Lirer, F., Bassetti, M.-A., Toucanne, S., Jorry, S. J., Insinga, D. D., Petrosino, P., and Châles, F.: Deltaic and Coastal Sediments as Recorders of Mediterranean Regional Climate and Human Impact Over the Past Three Millennia, Paleoceanogr. Paleoclimatology, 33(6), 579-593, https://doi.org/10.1029/2017PA003298, 2018.

Juggins, S.: Rioja: analysis of Quaternary science data, R package version (0.9-15.1), https://cran.rproject.org/web/packages/rioja/index.html, 2020.

Kennett, J. P.: Cenozoic evolution of Antarctic glaciation, the circum-Antarctic Ocean, and their impact on global paleoceanography, J. Geophys. Res., 82(27), 3843-3860, https://doi.org/10.1029/JC082i027p03843, 1977.

Kershaw, A.P.: Australasia, in: Vegetation History, edited by: Huntley, B., and Webb, T., Kluwer Academic Publisher, Dordrecht, The Netherlands, pp. 237-306, 1988.

Kershaw, P. and Wagstaff, B.: The Southern Conifer Family Araucariaceae: History, Status, and Value for Paleoenvironmental Reconstruction, Annu. Rev. Ecol. Syst., 32(1), 397-414, https://doi.org/10.1146/annurev.ecolsys.32.081501.114059, 2001.

King, E. C. and Barker, P. F.: The margins of the South Orkney microcontinent, J. Geol. Soc. London., 145(2), 317 LP - 331, https://doi.org/10.1144/gsjgs.145.2.0317, 1988.

Kirshner, A. E., Anderson, J. B., and Wellner, J. S.: Cenozoic glacial history of the northern Antarctic Peninsula: a micromorphological investigation of quartz sand grains, in: Tectonic, Climatic, and Cryospheric Evolution of the Antarctic peninsula, vol. 63, American Geophysical Union Washington, DC, 153-165, https://doi.org/ 10.1029/2010SP001046, 2011.

Klages, J. P., Salzmann, U., Bickert, T., Hillenbrand, C.-D., Gohl, K., Kuhn, G., Bohaty, S. M., Titschack, J., Müller, J., and Frederichs, T.: Temperate rainforests near the South Pole during peak Cretaceous warmth, Nature, 580(7801), 8186, https://doi.org/10.1038/s41586-020-2148-5, 2020.

735 Kolattukudy, P.E., Croteau, R., Buckner, J.S., Biochemistry of plant waxes, in: Chemistry and Biochemistry of Natural Waxes, edited by: Durig, J. R., and Kolattukudy, P.E., Elsevier Scientific Publishing Company, California, 1976.

Kühl, N., Gebhardt, C., Litt, T., and Hense, A.: Probability Density Functions as Botanical-Climatological Transfer Functions for Climate Reconstruction, Quat. Res., 58(3), 381-392, https://doi.org/10.1006/qres.2002.2380, 2002.

Larcher, W. and Winter, A.: Frost suceptibility of palms: experimental data and their interpretation., Principes, 25, 143-155, 1981.

Lawver, L. A. and Gahagan, L. M.: Opening of Drake Passage and its impact on Cenozoic ocean circulation, in Tectonic Boundary Conditions for Climate Reconstructions, edited by T. J. Crowley, and K. C. Burke, Oxford Univ. Press, New York, 212-223, 1998. 
https://doi.org/10.5194/cp-2021-84

Preprint. Discussion started: 16 July 2021

(c) Author(s) 2021. CC BY 4.0 License.

Leathwick, J. R.: Are New Zealand's Nothofagus species in equilibrium with their environment?, J. Veg. Sci., 9(5), 719-732, https://doi.org/10.2307/3237290, 1998.

Lewis, A. R., Marchant, D. R., Ashworth, A. C., Hedenäs, L., Hemming, S. R., Johnson, J. V, Leng, M. J., Machlus, M. L., Newton, A. E., Raine, J. I., Willenbring, J. K., Williams, M., and Wolfe, A. P.: Mid-Miocene cooling and the extinction of tundra in continental Antarctica, Proc. Natl. Acad. Sci., 105, 10676-10680, https://doi.org/10.1073/pnas.0802501105, 2008.

Lepp, A. P.: Geochemical and Sedimentological Analysis of Marine Sediments from ODP Site 696 and Implications for the Onset of Antarctic Glaciation, M. S. thesis, Montclair State University, Montclair, New Jersey, 2018.

Liu, Z., Pagani, M., Zinniker, D., DeConto, R., Huber, M., Brinkhuis, H., Shah, S. R., Leckie, R. M., and Pearson, A.: Global Cooling During the Eocene-Oligocene Climate Transition, Science, 323, 1187 LP - 1190, https://doi.org/10.1126/science.1166368, 2009.

Livermore, R., Hillenbrand, C., Meredith, M., and Eagles, G.: Drake Passage and Cenozoic climate: an open and shut case?, Geochemistry, Geophys. Geosystems, 8(1), https://doi.org/10.1029/2005GC001224, 2007.

López-Quirós, A., Escutia, C., Sánchez-Navas, A., Nieto, F., Garcia-Casco, A., Martín-Algarra, A., Evangelinos, D., and Salabarnada, A.: Glaucony authigenesis, maturity and alteration in the Weddell Sea: An indicator of paleoenvironmental conditions before the onset of Antarctic glaciation, Sci. Rep., 9(1), 13580, https://doi.org/10.1038/s41598-019-50107-1, 2019.

López-Quirós, A., Sánchez-Navas, A., Nieto, F., Escutia, C., 2020. New insights into the nature of glauconite. American Mineralogist 105, 674-686.

López-Quirós, A., Escutia, C., Etourneau, J., Rodríguez-Tovar, F. J., Roignant, S., Lobo, F. J., Thompson, N., Bijl, P. K., Bohoyo, F., Salzmann, U., Evangelinos, D., Salabarnada, A., Hoem, F. S., Sicre, M. A.: Eocene-Oligocene paleoenvironmental changes in the South Orkney Microcontinent (Antarctica) linked to the opening of Powell Basin, [in review].

Luo, Q., Zhong, N., Zhu, L., Wang, Y., Qin, J., Qi, L., Zhang, Y., and Ma, Y.: Correlation of burial organic carbon and paleoproductivity in the Mesoproterozoic Hongshuizhuang Formation, northern North China, Chinese Sci. Bull., 58(11), 1299-1309, 2013.

Lusk, C. H., Jorgensen, M. A., and Bellingham, P. J.: A conifer-angiosperm divergence in the growth vs. shade tolerance trade-off underlies the dynamics of a New Zealand warm-temperate rain forest, J. Ecol., 103(2), 479-488, https://doi.org/10.1111/1365-2745.12368, 2015.

Lyle, M., Murray, D. W., Finney, B. P., Dymond, J., Robbins, J. M., and Brooksforce, K.: The record of Late Pleistocene biogenic sedimentation in the eastern tropical Pacific Ocean, Paleoceanography, 3(1), 39-59, https://doi.org/10.1029/PA003i001p00039, 1988.

Macphail, M. K.: Palynostratigraphy of the murray basin, inland Southeastern Australia, 23(1), 197-240, https://doi.org/10.1080/01916122.1999.9989528, 1999. 
https://doi.org/10.5194/cp-2021-84

Preprint. Discussion started: 16 July 2021

(c) Author(s) 2021. CC BY 4.0 License.

Macphail, M. and Cantrill, D. J.: Age and implications of the Forest Bed, Falkland Islands, southwest Atlantic Ocean: Evidence from fossil pollen and spores, Palaeogeogr. Palaeoclimatol. Palaeoecol., 240(3), 602-629, https://doi.org/ 10.1016/j.palaeo.2006.03.010, 2006.

Mahiques, M. M. de, Hanebuth, T. J. J., Nagai, R. H., Bícego, M. C., Figueira, R. C. L., Sousa, S. H. M., Burone, L., FrancoFraguas, P., Taniguchi, S., and Salaroli, A. B.: Inorganic and organic geochemical fingerprinting of sediment sources and ocean circulation on a complex continental margin (São Paulo Bight, Brazil), Ocean Sci., 13, 209-222, https://doi.org/10.5194/os-13-209-2017, 2017.

Meyers, P. A. and Ishiwatari, R.: Lacustrine organic geochemistry — an overview of indicators of organic matter sources and diagenesis in lake sediments, Org. Geochem., 20(7), 867-900, https://doi.org/10.1016/0146-6380(93)90100-P, 1993.

Meyers, P. A.: Organic geochemical proxies of paleoceanographic, paleolimnologic, and paleoclimatic processes, Org. Geochem., 27(5), 213-250, https://doi.org/10.1016/S0146-6380(97)00049-1, 1997.

Mohr, B. A. R.: Eocene and Oligocene sporomorphs and dinoflagellate cysts from Leg 113 drill sites, Weddell Sea, Antarctica, in: Proceedings of the Ocean Drilling Program, scientific results, 595-612, 1990.

Moossen, H., Bendle, J., Seki, O., Quillmann, U., and Kawamura, K.: North Atlantic Holocene climate evolution recorded by high-resolution terrestrial and marine biomarker records, Quat. Sci. Rev., 129, 111-127, https://doi.org/10.1016/j.quascirev.2015.10.013, 2015.

Morris, E. K., Caruso, T., Buscot, F., Fischer, M., Hancock, C., Maier, T. S., Meiners, T., Müller, C., Obermaier, E., Prati, D., Socher, S. A., Sonnemann, I., Wäschke, N., Wubet, T., Wurst, S., and Rillig, M. C.: Choosing and using diversity indices: insights for ecological applications from the German Biodiversity Exploratories, Ecol. Evol., 4(18), 3514 3524, https://doi.org/10.1002/ece3.1155, 2014.

Newnham, R., McGlone, M., Moar, N., Wilmshurst, J., and Vandergoes, M.: The vegetation cover of New Zealand at the Last Glacial Maximum, Quat. Sci. Rev., 74, 202-214, https://doi.org/10.1016/j.quascirev.2012.08.022, 2013.

Nichols, J. E., Booth, R. K., Jackson, S. T., Pendall, E. G., and Huang, Y.: Paleohydrologic reconstruction based on n-alkane distributions in ombrotrophic peat, Org. Geochem., 37(11), 1505-1513, https://doi.org/10.1016/j.orggeochem.2006.06.020, 2006.

Nott, C. J., Xie, S., Avsejs, L. A., Maddy, D., Chambers, F. M., and Evershed, R. P.: n-Alkane distributions in ombrotrophic mires as indicators of vegetation change related to climatic variation, Org. Geochem., 31(2), 231-235, https://doi.org/10.1016/S0146-6380(99)00153-9, 2000.

Oksanen, J., Blanchet, F. G., Kindt, R., Legendre, P., Minchin, P. R., O’hara, R. B., Simpson, G. L., Solymos, P., Stevens, M. H. H., and Wagner, H.: Package 'vegan,' Community ecology package, version 2.5-7, cran [code], 2013.

Pancost, R. D., Baas, M., van Geel, B., and Sinninghe Damsté, J. S.: Biomarkers as proxies for plant inputs to peats: an example from a sub-boreal ombrotrophic bog, Org. Geochem., 33(7), 675-690, https://doi.org/10.1016/S01466380(02)00048-7, 2002. 
https://doi.org/10.5194/cp-2021-84

Preprint. Discussion started: 16 July 2021

(c) Author(s) 2021. CC BY 4.0 License.

\section{(c) (i)}

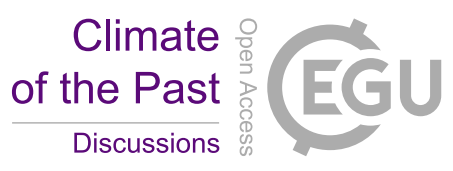

Poole, A.L.: Southern beeches, Science Information Publishing Centre, DSIR information series no. 162, Wellington, New Zealand, 1987.

Poole, I., Hunt, R. J., and Cantrill, D. J.: A Fossil Wood Flora from King George Island: Ecological Implications for an Antarctic Eocene Vegetation, Ann. Bot., 88(1), 33-54, https://doi.org/10.1006/anbo.2001.1425, 2001.

Poole, I., Mennega, A. M. W., and Cantrill, D. J.: Valdivian ecosystems in the Late Cretaceous and Early Tertiary of Antarctica: further evidence from myrtaceous and eucryphiaceous fossil wood, Rev. Palaeobot. Palynol., 124(1), 9-27, https://doi.org/10.1016/S0034-6667(02)00244-0, 2003.

Poynter, J. G., Farrimond, P., Robinson, N., and Eglinton, G.: Aeolian-Derived Higher Plant Lipids in the Marine Sedimentary Record: Links with Palaeoclimate, in: Paleoclimatology and Paleometeorology: Modern and Past Patterns of Global Atmospheric Transport, edited by: Leinen, M. and Sarnthein, M., Springer Netherlands, Dordrecht, 435-462, https://doi.org/10.1007/978-94-009-0995-3_18, 1989.

Prebble, J. G., Raine, J. I., Barrett, P. J., and Hannah, M. J.: Vegetation and climate from two Oligocene glacioeustatic sedimentary cycles (31 and $24 \mathrm{Ma}$ ) cored by the Cape Roberts Project, Victoria Land Basin, Antarctica, Palaeogeogr. Palaeoclimatol. Palaeoecol., 231(1), 41-57, https://doi.org/10.1016/j.palaeo.2005.07.025, 2006.

Pross, J., Contreras, L., Bijl, P. K., Greenwood, D. R., Bohaty, S. M., Schouten, S., Bendle, J. A., Röhl, U., Tauxe, L., Raine, J. I., Huck, C. E., van de Flierdt, T., Jamieson, S. S. R., Stickley, C. E., van de Schootbrugge, B., Escutia, C., Brinkhuis, H., Brinkhuis, H., Escutia Dotti, C., Klaus, A., Fehr, A., Williams, T., Bendle, J. A. P., Bijl, P. K., Bohaty, S. M., Carr, S. A., Dunbar, R. B., Gonzàlez, J. J., Hayden, T. G., Iwai, M., Jimenez-Espejo, F. J., Katsuki, K., Soo Kong, G., McKay, R. M., Nakai, M., Olney, M. P., Passchier, S., Pekar, S. F., Pross, J., Riesselman, C. R., Röhl, U., Sakai, T., Shrivastava, P. K., Stickley, C. E., Sugisaki, S., Tauxe, L., Tuo, S., van de Flierdt, T., Welsh, K., Yamane, M., and Scientists, I. O. D. P. E. 318: Persistent near-tropical warmth on the Antarctic continent during the early Eocene epoch, Nature, 488(7409), 73-77, https://doi.org/10.1038/nature11300, 2012.

Punyasena, S.W., Dalling, J.W., Jaramillo, C., Turner, B.L.: The response of vegetation on the Andean flank in western Amazonia to Pleistocene climate change, Science, 331(6020), 1055-1058, https://doi.org/10.1126/science.1197947, 2011.

R Development Core Team: R: A language and environment for statistical computing, 2013.

Raine, J. I.: Terrestrial palynomorphs from Cape Roberts Project drillhole CRP-1, Ross Sea, Antarctica, Terra Antart., 5(3), 539-548, 1998.

Raine, J. I. and Askin, R. A.: Terrestrial palynology of Cape Roberts Project drillhole CRP-3, Victoria Land Basin, Antarctica, Terra Antart., 8, 389-400, 2001.

Raine, J.I., Mildenhall, D.C. and Kennedy, E.: New Zealand fossil spores and pollen: an illustrated catalogue, https://www.gns.cri.nz/what/earthhist/fossils/spore_pollen/catalog/index.htm, 2011.

Raup, D. M.: Taxonomic diversity estimation using rarefaction, Paleobiology, 333-342, 1975. 
https://doi.org/10.5194/cp-2021-84

Preprint. Discussion started: 16 July 2021

(c) Author(s) 2021. CC BY 4.0 License.

(c) (i)

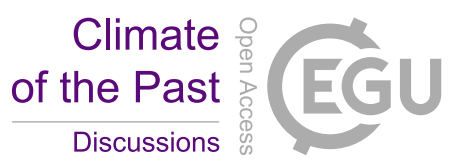

Rawlence, N. J., Potter, B. C. M., Dussex, N., Scarsbrook, L., Orlovich, D. A., Waters, J. M., McGlone, M., and Knapp, M.: Plio-Pleistocene environmental changes shape present day phylogeography of New Zealand's southern beeches (Nothofagaceae), New Zeal. J. Bot., 59(1), 55-71, https://doi.org/10.1080/0028825X.2020.1791915, 2021.

Reichgelt, T., Kennedy, E. M., Jones, W. A., Jones, D. T., and Lee, D. E.: Contrasting palaeoenvironments of the mid/late Miocene Dunedin Volcano, southern New Zealand: Climate or topography?, Palaeogeogr. Palaeoclimatol. Palaeoecol., 441, 696-703, https://doi.org/10.1016/j.palaeo.2015.10.029, 2016.

Reichgelt, T., West, C. K., and Greenwood, D. R.: The relation between global palm distribution and climate, Sci. Rep., 8(1), 4721, https://doi.org/10.1038/s41598-018-23147-2, 2018.

Rielley, G., Collier, R. J., Jones, D. M., and Eglinton, G.: The biogeochemistry of Ellesmere Lake, U.K.-I: source correlation of leaf wax inputs to the sedimentary lipid record, Org. Geochem., 17(6), 901-912, https://doi.org/10.1016/01466380(91)90031-E, 1991.

Robert, C. and Maillot, H.: Palaeoenvironments in the Weddell Sea area and Antarctic climates, as deduced from clay mineral associations and geochemical data, ODP Leg 113, in: Proceedings of the Ocean Drilling Program, scientific results, 51-66, 1990.

Romero, E. J. and Zamaloa, M. C.: Polen de Angiospermas de la Formacion Rio Turbio (Eoceno), Provincia de Santa Cruz, Republica Argentina, Ameghiniana, 22 (1-2), 43-51, 1985.

Romero, E.J. and Castro, M.T.: Material fúngico y granos de polen de angiospermas de la Formación Río Turbio (Eoceno), provincial de Santa Cruz, República Argentina, Ameghiniana, 23(1-2), 101-118, 1986.

Rommerskirchen, F., Eglinton, G., Dupont, L., and Rullkötter, J.: Glacial/interglacial changes in southern Africa: Compoundspecific $\delta 13 \mathrm{C}$ land plant biomarker and pollen records from southeast Atlantic continental margin sediments, Geochemistry, Geophys. Geosystems, 7(8), https://doi.org/10.1029/2005GC001223, 2006.

Sangiorgi, F., Bijl, P. K., Passchier, S., Salzmann, U., Schouten, S., McKay, R., Cody, R. D., Pross, J., van de Flierdt, T., Bohaty, S. M., Levy, R., Williams, T., Escutia, C., and Brinkhuis, H.: Southern Ocean warming and Wilkes Land ice sheet retreat during the mid-Miocene, Nat. Commun., 9(1), 317, https://doi.org/10.1038/s41467-017-02609-7, 2018.

Sarkar, S., Basak, C., Frank, M., Berndt, C., Huuse, M., Badhani, S., and Bialas, J.: Late Eocene onset of the Proto-Antarctic Circumpolar Current, Sci. Rep., 9(1), 10125, https://doi.org/10.1038/s41598-019-46253-1, 2019.

Sarnthein, M., Winn, K., Duplessy, J.-C., and Fontugne, M. R.: Global variations of surface ocean productivity in low and mid latitudes: Influence on $\mathrm{CO} 2$ reservoirs of the deep ocean and atmosphere during the last 21,000 years, Paleoceanography, 3(3), 361-399, https://doi.org/10.1029/PA003i003p00361, 1988.

Schefuß, E., Ratmeyer, V., Stuut, J.-B. W., Jansen, J. H. F., and Sinninghe Damsté, J. S.: Carbon isotope analyses of n-alkanes in dust from the lower atmosphere over the central eastern Atlantic, Geochim. Cosmochim. Acta, 67(10), 1757-1767, https://doi.org/10.1016/S0016-7037(02)01414-X, 2003. 
https://doi.org/10.5194/cp-2021-84

Preprint. Discussion started: 16 July 2021

(c) Author(s) 2021. CC BY 4.0 License.

\section{(c) (i)}

Climate
of the Past

Discussions

Scher, H. D. and Martin, E. E.: Oligocene deep water export from the North Atlantic and the development of the Antarctic Circumpolar Current examined with neodymium isotopes, Paleoceanography, 23, https://doi.org/10.1029/2006PA001400, 2008.

Shannon, C. E.: A mathematical theory of communication, Bell Syst. Tech. J., 27(3), 379-423, https://doi.org/10.1002/j.15387305.1948.tb01338.x, 1948.

Sicre, M.-A. and Peltzer, E. T.: Lipid geochemistry of remote aerosols from the southwestern Pacific Ocean sector, Atmos. Environ., 38(11), 1615-1624, https://doi.org/10.1016/j.atmosenv.2003.12.012, 2004.

Specht, R. L., Dettmann, M. E., and Jarzen, D. M.: Community associations and structure in the Late Cretaceous vegetation of southeast Australasia and Antarctica, Palaeogeogr. Palaeoclimatol. Palaeoecol., 94(1), 283-309, https://doi.org/10.1016/0031-0182(92)90124-N, 1992.

Thompson, N., Salzmann, U., López-Quirós, A., Bijl, P. K., Hoem, F. S., Etourneau, J., Marie-Alexandrine, S., Roignant, S., Hocking, E., Amoo, M., Escutia, C.: ODP Site 696B Sporomorph Count data, Diversity, DCA and Climate estimate calculations, PANGEA [data set], awaiting validation.

Tomlinson, P. B.: The uniqueness of palms, Bot. J. Linn. Soc., 151(1), 5-14, https://doi.org/10.1111/j.10958339.2006.00520.x, 2006.

Traverse, A. (Eds): Paleopalynology (Vol. 28), Springer Science \& Business Media, 2007.

Truswell, E. M. and Macphail, M. K.: Polar forests on the edge of extinction: what does the fossil spore and pollen evidence from East Antarctica say?, Aust. Syst. Bot., 22(2), 57-106, https://doi.org/10.1071/SB08046, 2009.

van de Lagemaat, S. H. A., Swart, M. L. A., Vaes, B., Kosters, M. E., Boschman, L. M., Burton-Johnson, A., Bijl, P. K., Spakman, W., and van Hinsbergen, D. J. J.: Subduction initiation in the Scotia Sea region and opening of the Drake Passage: When and why?, Earth-Sci. Rev., 215, 103551, https://doi.org/10.1016/j.earscirev.2021.103551, 2021.

Veblen, T.T., Schlegel, F. M., Oltremari, V. J.: Temperate broad-leaved evergreen forests of South America, in: Temperate Broad-Leaved Forests, edited by: Ovington, J. D., Elsevier, Amsterdam, Netherlands, 5-31, 1983.

Veblen, T. T., Donoso, C., Kitzberger, T., and Rebertus, A. J.: Ecology of southern Chilean and Argentinean Nothofagus forests, Ecol. Biogeogr. Nothofagus For., 10, 93-353, 1996.

Villa, G., Fioroni, C., Pea, L., Bohaty, S., and Persico, D.: Middle Eocene-late Oligocene climate variability: calcareous nannofossil response at Kerguelen Plateau, Site 748, Mar. Micropaleontol., 69, 173-192, https://doi.org/10.1016/j.marmicro.2008.07.006, 2008.

Vogts, A., Moossen, H., Rommerskirchen, F., and Rullkötter, J.: Distribution patterns and stable carbon isotopic composition of alkanes and alkan-1-ols from plant waxes of African rain forest and savanna C3 species, Org. Geochem., 40(10), 1037-1054, https://doi.org/10.1016/j.orggeochem.2009.07.011, 2009.

Wardle, J.: The New Zealand beeches: ecology, utilisation and management., New Zealand Forest Service, 1984.

Warny, S., Askin, R., Anderson, J. B., and Wellner, J. S.: Vegetation and organic-walled phytoplankton at the end of the Antarctic greenhouse world: Latest Eocene cooling events, in: Tectonic, Climatic, and Cryospheric Evolution of the 
https://doi.org/10.5194/cp-2021-84

Preprint. Discussion started: 16 July 2021

(c) Author(s) 2021. CC BY 4.0 License.

\section{(c) (i)}

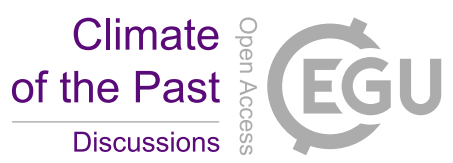

Antarctic peninsula, vol. 63, American Geophysical Union Washington, DC, 63, 193-210, https://doi.org/10.1029/2010SP000965, 2011a.

Warny, S. and Askin, R.: Last remnants of Cenozoic vegetation and organic-walled phytoplankton in the Antarctic Peninsula's icehouse world, in: Tectonic, Climatic, and Cryospheric Evolution of the Antarctic peninsula, vol. 63, American Geophysical Union Washington, DC, 167-192, https://doi.org/10.1029/2010SP000996, 2011 b.

915 Warny, S., Kymes, C. M., Askin, R., Krajewski, K. P., and Tatur, A.: Terrestrial and marine floral response to latest Eocene and Oligocene events on the Antarctic Peninsula, 43(1), 4-21, https://doi.org/10.1080/01916122.2017.1418444, 2019.

Wei, W. and Wise, S.: Middle Eocene to Pleistocene calcareous nannofossils recovered by ocean drilling program leg 113 in the Weddell Sea, in: Proceedings of the Ocean Drilling Program, scientific results, 639-666, 1990.

Wellner, J. S., Anderson, J. B., Ehrmann, W., Weaver, F. M., Kirshner, A., Livsey, D., and Simms, A. R.: History of an evolving ice sheet as recorded in SHALDRIL cores from the northwestern Weddell Sea, Antarctica, in: Tectonic, Climatic, and Cryospheric Evolution of the Antarctic peninsula, vol. 63, American Geophysical Union Washington, DC, 131-152, https://doi.org/ 10.1029/2010SP001047, 2011.

Westerhold, T., Marwan, N., Drury, A. J., Liebrand, D., Agnini, C., Anagnostou, E., Barnet, J. S. K., Bohaty, S. M., De Vleeschouwer, D., Florindo, F., Frederichs, T., Hodell, D. A., Holbourn, A. E., Kroon, D., Lauretano, V., Littler, K., Lourens, L. J., Lyle, M., Pälike, H., Röhl, U., Tian, J., Wilkens, R. H., Wilson, P. A., and Zachos, J. C.: An astronomically dated record of Earth's climate and its predictability over the last 66 million years, Science, 369(6509), 1383 LP - 1387, https://doi.org/10.1126/science.aba6853, 2020.

Wigley, R. A. and Compton, J. S.: Late Cenozoic evolution of the outer continental shelf at the head of the Cape Canyon, South Africa, Mar. Geol., 226(1-2), 1-23, https://doi.org/10.1016/j.margeo.2005.09.015, 2006.

Willard, D. A., Donders, T. H., Reichgelt, T., Greenwood, D. R., Sangiorgi, F., Peterse, F., Nierop, K. G. J., Frieling, J., Schouten, S., and Sluijs, A.: Arctic vegetation, temperature, and hydrology during Early Eocene transient global warming events, Glob. Planet. Change, 178, 139-152, https://doi.org/10.1016/j.gloplacha.2019.04.012, 2019.

Wilson, D. S., Jamieson, S. S. R., Barrett, P. J., Leitchenkov, G., Gohl, K., and Larter, R. D.: Antarctic topography at the Eocene-Oligocene boundary, Palaeogeogr. Palaeoclimatol. Palaeoecol., 335-336, 24-34, https://doi.org/10.1016/j.palaeo.2011.05.028, 2012.

Wilson, D. S., Pollard, D., DeConto, R. M., Jamieson, S. S. R., and Luyendyk, B. P.: Initiation of the West Antarctic Ice Sheet and estimates of total Antarctic ice volume in the earliest Oligocene, Geophys. Res. Lett., 40(16), 4305-4309, https://doi.org/10.1002/grl.50797, 2013.

940 Zachos, J., Pagani, M., Sloan, L., Thomas, E., and Billups, K.: Trends, Rhythms, and Aberrations in Global Climate 65 Ma to Present, Science, 292(5517), 686 LP - 693, https://doi.org/10.1126/science.1059412, 2001.

Zachos, J. C., Dickens, G. R., and Zeebe, R. E.: An early Cenozoic perspective on greenhouse warming and carbon-cycle dynamics, Nature, 451(7176), 279-283, https://doi.org/10.1038/nature06588, 2008. 
https://doi.org/10.5194/cp-2021-84

Preprint. Discussion started: 16 July 2021

(C) Author(s) 2021. CC BY 4.0 License.

Zhang, R. and Delworth, T. L.: Simulated tropical response to a substantial weakening of the Atlantic thermohaline circulation,

$$
\text { J. Clim., 18(12), 1853-1860, } 2005 .
$$

Zhou, W., Xie, S., Meyers, P. A., and Zheng, Y.: Reconstruction of late glacial and Holocene climate evolution in southern China from geolipids and pollen in the Dingnan peat sequence, Org. Geochem., 36(9), 1272-1284, https://doi.org/10.1016/j.orggeochem.2005.04.005, 2005.

Table captions

950 Table 1: Revised age model for Ocean Drilling Program (ODP) Leg 113 Site determined by calcareous nannofossil and dinoflagellate cysts biostratigraphy $(\mathrm{FO}=$ First occurrence, $\mathrm{FCO}=$ Fist common occurrence $)$

Table 2: List of fossil pollen and spore taxa and their NLR used in sporomorph-based climate estimates from ODP Site 696.

Figure captions

Figure 1: Modern day geographical and tectonic setting of the study area, showing location of ODP Site 696 on the southeastern margin of the SOM (red circle), and litho-tectonic units superimposed for the Antarctic Peninsula and southern South America (modified after Elliot, 1988). Tectonic setting and features after Maldonado et al. (2015). APR, Antarctic-Phoenix Ridge; BB, Bruce Bank; Sea; DB, Discovery Bank; DvB, Dove Basin; EB, Endurance Basin; ESR, East Scotia Ridge; FP, Falkland Plateau; HB, Herman Bank; JB, Jane Basin; JBk, Jane Bank; OB, Ona Basin; PB, Powell Basin; PBk, Protector Bank; PrB, Protector Basin; SB, Scan Basin; SGM, South Georgia Microcontinent; SI, Seymour Island; SOM, South Orkney Microcontinent; SSIB, South Shetland

960 Islands Block; TR, Terror Rise; WSR, West Scotia Ridge; and WSS, West Scotia Sea. (Adapted from López-Quirós et al., 2019, in review).

Figure 2: Stratigraphy of the studied sedimentary interval from ODP Site 696 Hole B. From left to right: Simplified lithological log of ODP Site 696, Age-depth plot based on biostratigraphy, cores, detailed lithological log of Eocene-Oligocene Unit VII and clay mineral percentage. Biostratigraphic age constraints based on calcareous nannofossils (Wei and Wise, 1990) and dinoflagellate cysts

965 (Houben et al., 2013). Detailed lithological log from López-Quirós et al. (2019, in review). Clay minerals are from Robert and Maillot (1990). (Adapted from López-Quirós et al., 2019, in review).

Figure 3: Frequency and stratigraphic distribution of major pollen and spore taxa with CONISS ordination showing two distinct zones (Zone I and Zone II), Zone I further subdivided based on the occurrence of key taxa. Pollen and spore taxa have been separated into key ecological groups.

970 Figure 4: Sporomorph based quantitative climate estimates using probability density functions (PDF). From left to right: Coldest Month Mean Temperature (CMMT), Mean Annual Temperature (MAT), Warmest Month Mean Temperature (WMMT) and Mean Annual Precipitation (MAP).

Figure 5: Distribution of key vegetation and dinocyst groups plotted against diversity indices results, percentages of reworked terrestrial palynomorphs and $\boldsymbol{n}$-alkane variables/ratios. From left to right: Rarefaction analysis results at number of species per 50 and 100 specimens, percentage of reworked terrestrial palynomorphs, DCA axis 1 results, percentage of cryptogam taxa, percentage of angiosperm taxa (non-Nothofagus), percentage of gymnosperm taxa, percentage of Nothofagus, percentage of endemic-Antarctic dinocyst taxa, percentage of Protoperidiniaceae dinoflagellates, TOC, TI index, ACL, Paq and n-alkane n-C23/n-C29 ratios. Dinoflagellate abundance from Houben et al. (2013). Terrestrial biomarkers/n-alkane variables/ratios from López-Quirós et al. (in review).

980 Figure 6: Schematic representation of vegetation from Site 696, illustrating the response of key taxonomic group to climate and environmental change through key intervals during the late Eocene and early Oligocene. (A) Late Eocene vegetation ( $\sim 37.6-35.5$ Ma), during the deposition of Zone Ia vegetation was dominated by Nothofagus with secondary podocarps and an understory of cryptogams and minor angiosperms. Sporomorph-based climate estimates and the presence of paratropical taxa indicate conditions were relatively warm compared to the rest of the section; (B) Latest Eocene after late Eocene climate cooling ( 35.5-34.1 Ma), 985 vegetation remained similar to that of the late Eocene and was still dominated by Nothofagus, but climate cooling by around $2^{\circ} \mathrm{C}$ 
https://doi.org/10.5194/cp-2021-84

Preprint. Discussion started: 16 July 2021

(c) Author(s) 2021. CC BY 4.0 License.

resulted in loss of paratropical taxa and slight decrease in taxa diversity; (C) EOT vegetation during glacial onset ( 34.1 Ma), environmental disturbance caused by ice expansion and retreat resulted in the reduction of Nothofagus-dominated forested areas and increase in tundra-like vegetation; (D) early Oligocene ( 33.5-32.2 Ma), during glacial retreat and the development of milder climates disturbance and reduction of Nothofagus-dominated forests facilitated the expansion of more competitive Podocarpaceae and pioneer cryptogam taxa. 
https://doi.org/10.5194/cp-2021-84

Preprint. Discussion started: 16 July 2021

(c) Author(s) 2021. CC BY 4.0 License.

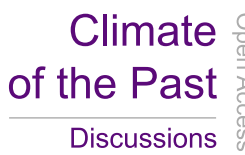

(c) (1)

Discussions

Table 1

\begin{tabular}{|c|c|c|c|c|c|c|c|c|c|}
\hline Event/Characteristic & Kind & $\begin{array}{l}\text { Lower } \\
\text { level }\end{array}$ & $\begin{array}{l}\text { Upper } \\
\text { level }\end{array}$ & $\begin{array}{c}\text { Bottom } \\
\text { depth }\end{array}$ & $\begin{array}{l}\text { Top } \\
\text { depth }\end{array}$ & $\begin{array}{l}\text { Mid- } \\
\text { depth }\end{array}$ & Reference & $\begin{array}{l}\text { Age } \\
\text { (Ma) }\end{array}$ & Reference \\
\hline $\begin{array}{ll}\text { FO } & \text { Chiropteridium } \\
\text { galea } & \end{array}$ & Dinocysts & $\begin{array}{l}53 \mathrm{R}-3 \\
80 \mathrm{~cm}\end{array}$ & $\begin{array}{l}53 \mathrm{R}-2 \\
130 \mathrm{~cm}\end{array}$ & 552.70 & 551.70 & 552.20 & Houben et al., 2019 & $<33.26$ & Pross et al., 2010 \\
\hline FO Malvinia escutiana & Dinocysts & $\begin{array}{l}55 \mathrm{R}-1 \\
117 \mathrm{~cm}\end{array}$ & $\begin{array}{l}55 \mathrm{R}-1 \\
62 \mathrm{~cm}\end{array}$ & 569.39 & 568.82 & 569.11 & Houben et al., 2013; 2019 & 33.6 & Houben et al., 2011 \\
\hline $\begin{array}{l}\text { FO Stoveracysta } \\
\text { kakanuiensis }\end{array}$ & Dinocysts & $\begin{array}{l}55 \mathrm{R}-3 \\
75 \mathrm{~cm}\end{array}$ & $\begin{array}{l}55 \mathrm{R}-2 \\
147 \mathrm{~cm}\end{array}$ & 571.95 & 571.16 & 571.55 & Houben et al., 2013; 2019 & 34.1 & Clowes, 1985 \\
\hline $\begin{array}{l}\text { FO Reticulofenestra } \\
\text { oamaruensis }\end{array}$ & $\begin{array}{l}\text { Calcareous } \\
\text { nannofossils }\end{array}$ & $\begin{array}{l}58 \mathrm{R}-1 \\
122 \mathrm{~cm}\end{array}$ & $\begin{array}{l}57 \mathrm{R}-1 \\
112 \mathrm{~cm}\end{array}$ & 598.42 & 588.72 & 593.57 & Wei and Wise, 1990 & 35.5 & Villa et al., 2008 \\
\hline $\begin{array}{l}\text { FCO Isthmolithus } \\
\text { recurvus }\end{array}$ & $\begin{array}{l}\text { Calcareous } \\
\text { nannofossils }\end{array}$ & $\begin{array}{l}60 \mathrm{R}-1 \\
36 \mathrm{~cm}\end{array}$ & $\begin{array}{l}59 \mathrm{R}- \\
\mathrm{CC}\end{array}$ & 616.96 & 616.6 & 616.78 & Wei and Wise, 1990 & 36.27 & Villa et al., 2008 \\
\hline $\begin{array}{l}\text { FO Reticulofenestra } \\
\text { bisecta }\end{array}$ & $\begin{array}{l}\text { Calcareous } \\
\text { nannofossils }\end{array}$ & $\begin{array}{l}62 \mathrm{R}-6 \\
132 \mathrm{~cm}\end{array}$ & - & 643.62 & - & 643.62 & Wei and Wise, 1990 & $<37.61$ & Villa et al., 2008 \\
\hline
\end{tabular}


https://doi.org/10.5194/cp-2021-84

Preprint. Discussion started: 16 July 2021

(c) Author(s) 2021. CC BY 4.0 License.

Climate

of the Past

Discussions

(c) (i)

Table 2

\begin{tabular}{|c|c|c|c|}
\hline Fossil taxa & Botanical affinity & Reference & $\begin{array}{c}\text { NLR used for climate } \\
\text { analysis }\end{array}$ \\
\hline Acaena sp. & Acaena & & Acaena \\
\hline Beaupreaidites cf. verrucosus & Proteaceae (Beauprea). & Raine et al. (2011) & Beauprea \\
\hline Chenopodipollis chenopodiaceoides & Chenopodiaceae & Raine et al. (2011) & Chenopodiaceae \\
\hline Clavatipollenites ascarinoides & Chloranthaceae (Ascarina). & Raine et al. (2011) & Ascarina \\
\hline Cupanieidites orthoteichus & Sapindaceae & Raine et al. (2011) & Sapindaceae \\
\hline Liliacidites intermedius & Liliaceae (?Arthropodium) & Raine et al. (2011) & Liliaceae \\
\hline Lymingtonia cf. cenozoica & Nyctaginaceae (Pisonia brunoniana) & Raine et al. (2011) & Pisonia \\
\hline Malvacipollis cf. subtilis & Malvaceae?/Euphorbiaceae & Raine et al. (2011) & Euphorbiaceae \\
\hline Myricipites harrisii & Casuarinaceae/Myricaceae & Raine et al. (2011) & Myricaceae \\
\hline Myrtaceidites cf. mesonesus & Myrtaceae (Metrosideros) & Raine et al. (2011) & Metrosideros \\
\hline Nothofagidites spp. & Nothofagaceae & Truswell \& Macphail (2009) & Nothofagaceae \\
\hline Microalatidites paleogenicus & Podocarpaceae (Phyllocladus) & Raine et al. (2011) & Phyllocladus \\
\hline Microcachryidites antarcticus & Podocarpaceae (Microcachrys tetragona) & Raine et al. (2011) & Podocarpaceae \\
\hline Phyllocladidites mawsonii & Podocarpaceae (Lagarostrobos franklinii). & Truswell \& Macphail (2009) & Lagarostrobos franklinii \\
\hline Podocarpidites spp. & Podocarpaceae (Podocarpus) & Truswell \& Macphail (2009) & Podocarpus \\
\hline Podosporites spp. & Podocarpaceae (cf. Microcachrys) & Raine et al. (2011) & Podocarpaceae \\
\hline Trichotomosulcites subgranulatus & Podocarpaceae (Microcachrys) & Raine et al. (2011) & Podocarpaceae \\
\hline \multicolumn{4}{|l|}{ Cryptogams } \\
\hline Baculatisporites comaumensis & Osmundaceae (Osmunda/Leptopteris) & Raine et al. (2011) & Osmundaceae \\
\hline Ceratosporites cf. equalis & Selaginellaceae (Selaginella) & Raine et al. (2011) & Selaginellaceae \\
\hline Coptospora archangelskyi & Bartramiaceae (Conostomum) & Raine (1998) & Conostomum \\
\hline Cyathidites spp. & Cyatheaceae & Raine et al. (2011) & Cyatheaceae \\
\hline Dictyophyllidites arcuatus & Gleicheniaceae (?Dicranopteris) & Raine et al. (2011) & Dicranopteris \\
\hline Foveotriletes lacunosus & Lycopodiaceae (Huperzia) & Raine et al. (2011) & Huperzia \\
\hline
\end{tabular}


https://doi.org/10.5194/cp-2021-84

Climate

Preprint. Discussion started: 16 July 2021

(c) Author(s) 2021. CC BY 4.0 License.

(c) (1)

Figure 1

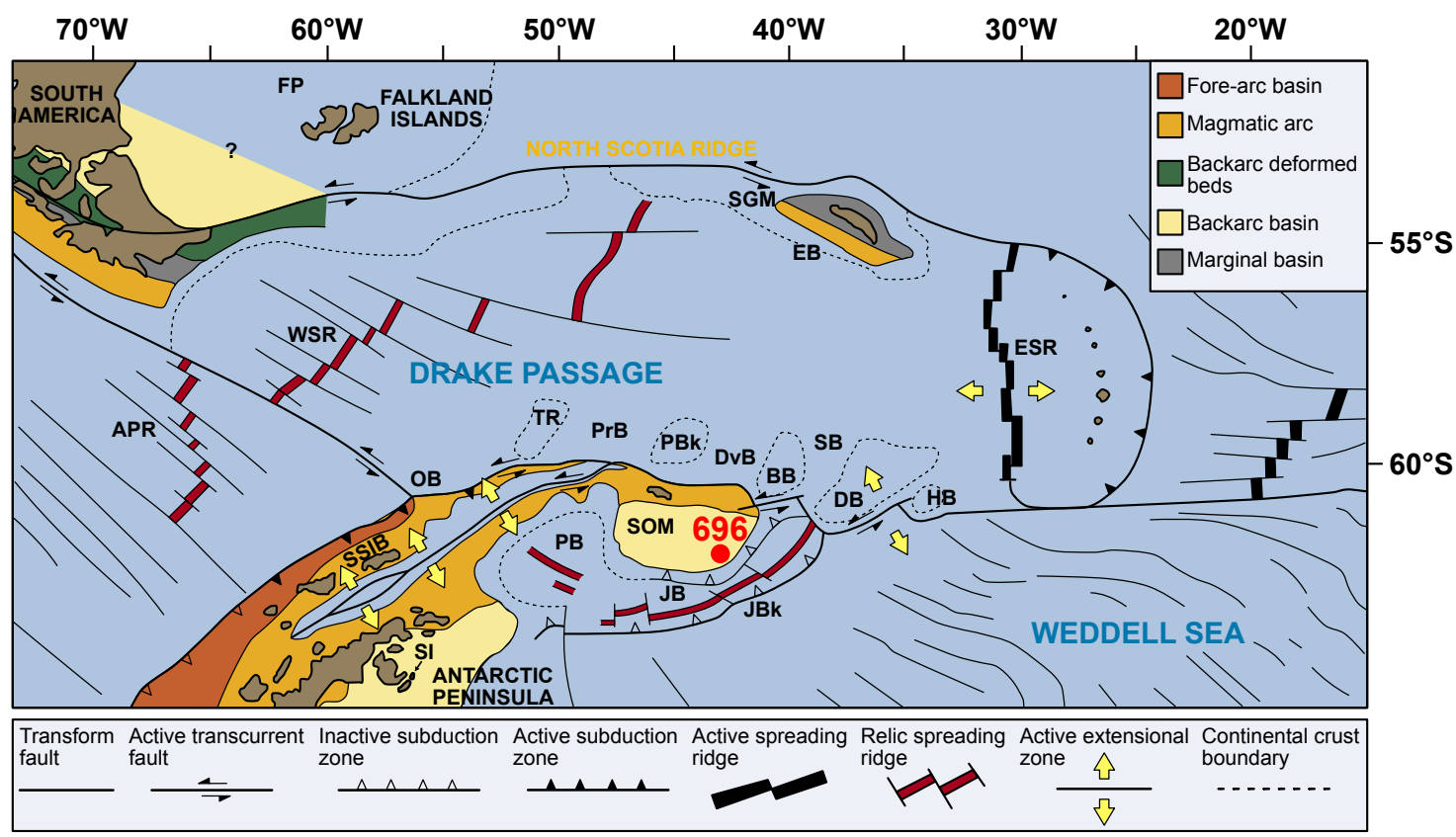


https://doi.org/10.5194/cp-2021-84

Climate

Preprint. Discussion started: 16 July 2021

(c) Author(s) 2021. CC BY 4.0 License.
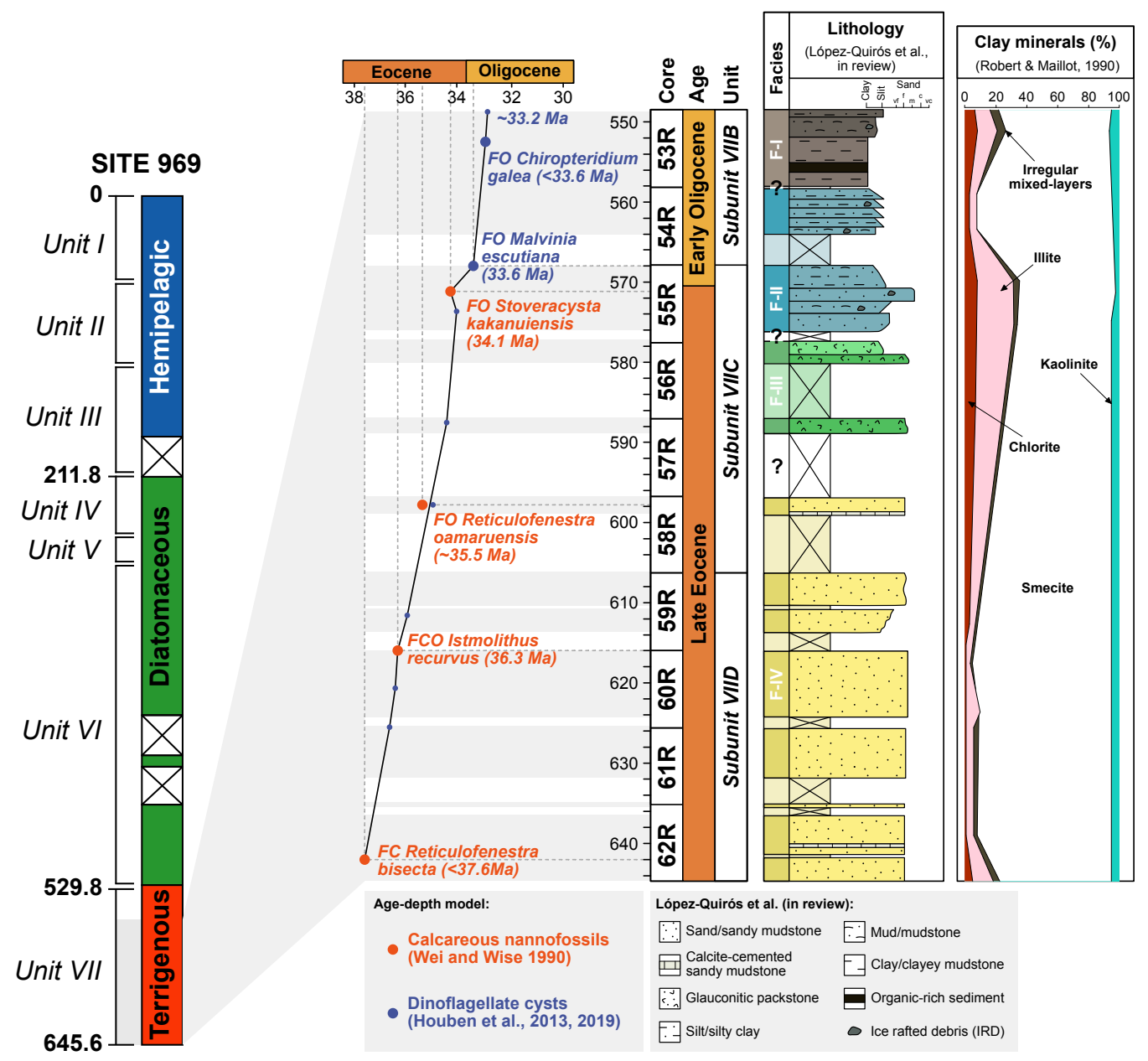
https://doi.org/10.5194/cp-2021-84

Preprint. Discussion started: 16 July 2021

(c) Author(s) 2021. CC BY 4.0 License.

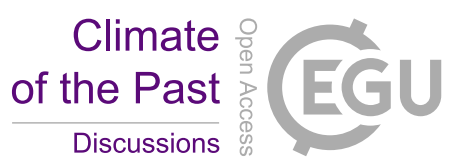

\section{Figure 3}

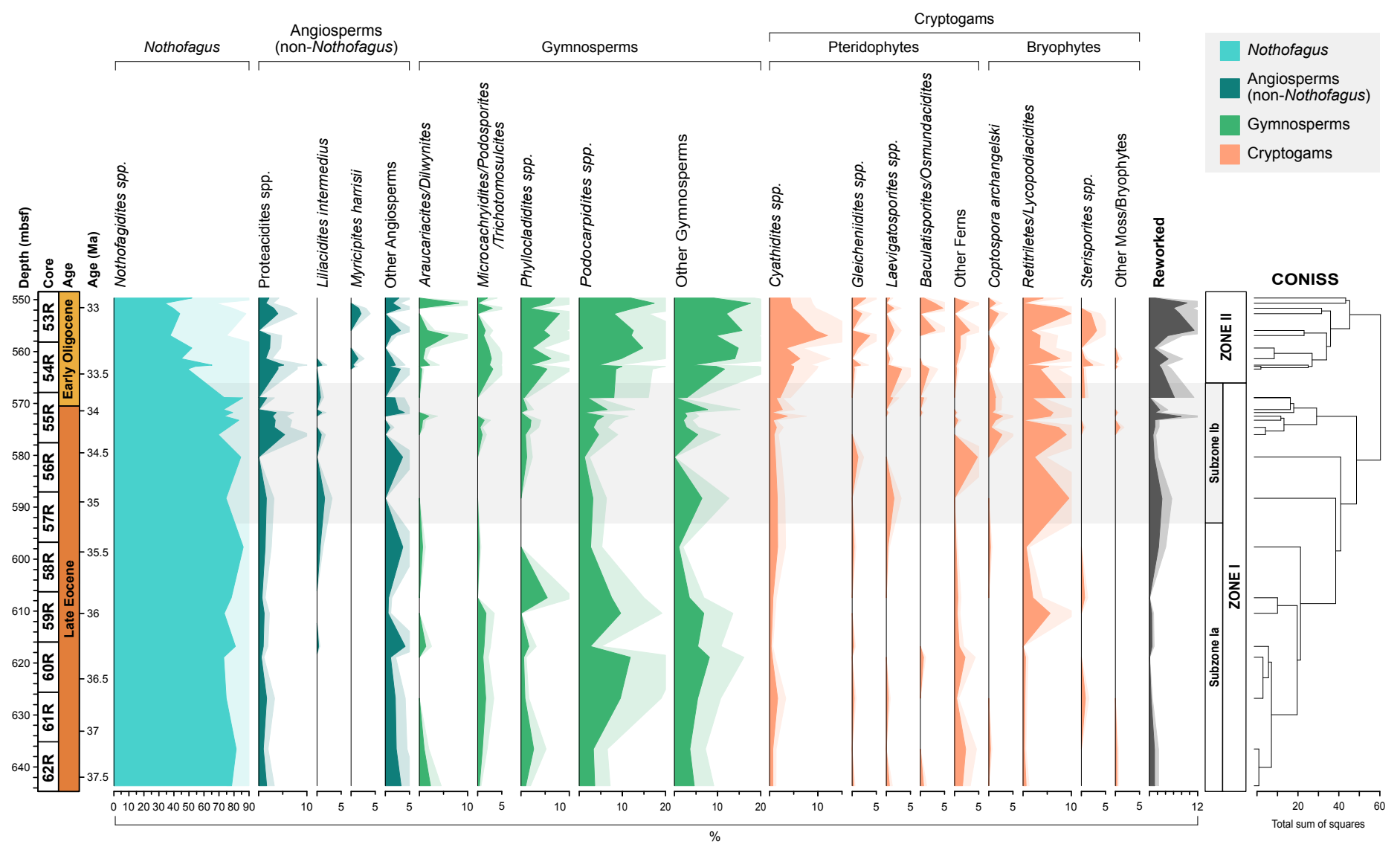


https://doi.org/10.5194/cp-2021-84

Climate

Preprint. Discussion started: 16 July 2021

(c) Author(s) 2021. CC BY 4.0 License.

Discussions

(c) (1)

Figure 4

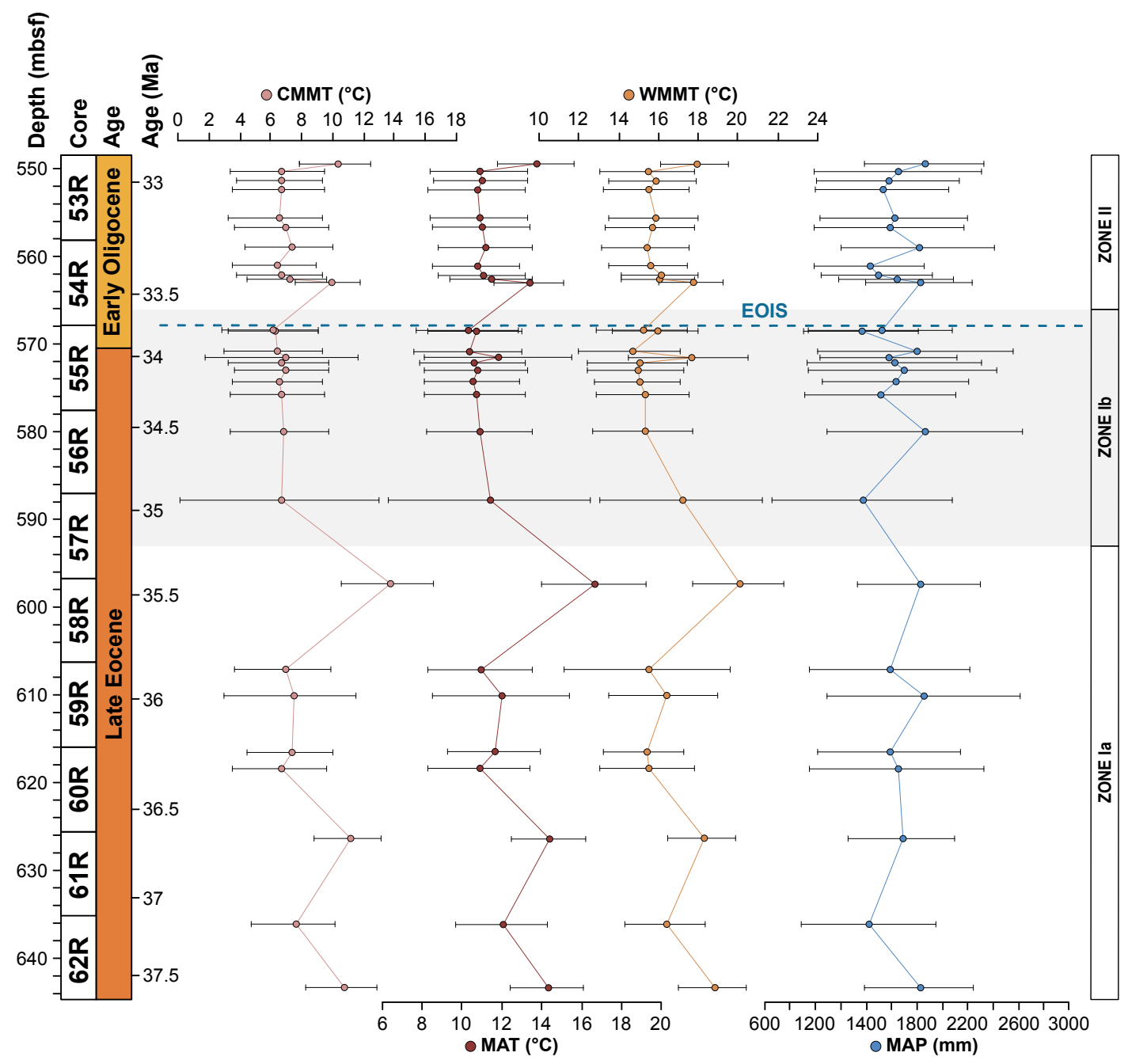

1090 
https://doi.org/10.5194/cp-2021-84

Preprint. Discussion started: 16 July 2021

(c) Author(s) 2021. CC BY 4.0 License.

Climate

(c) (1)

Discussions

Figure 5

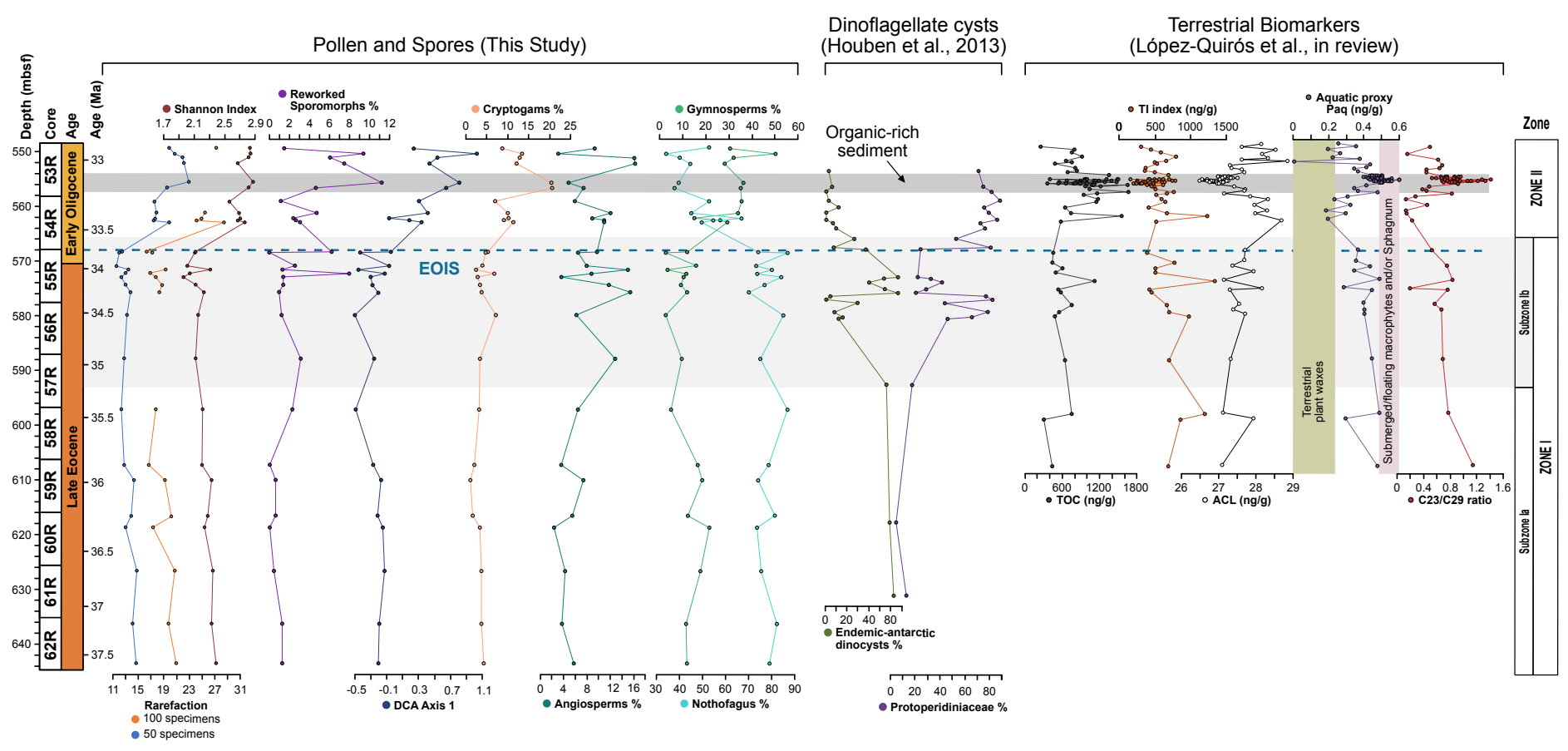


Figure 6
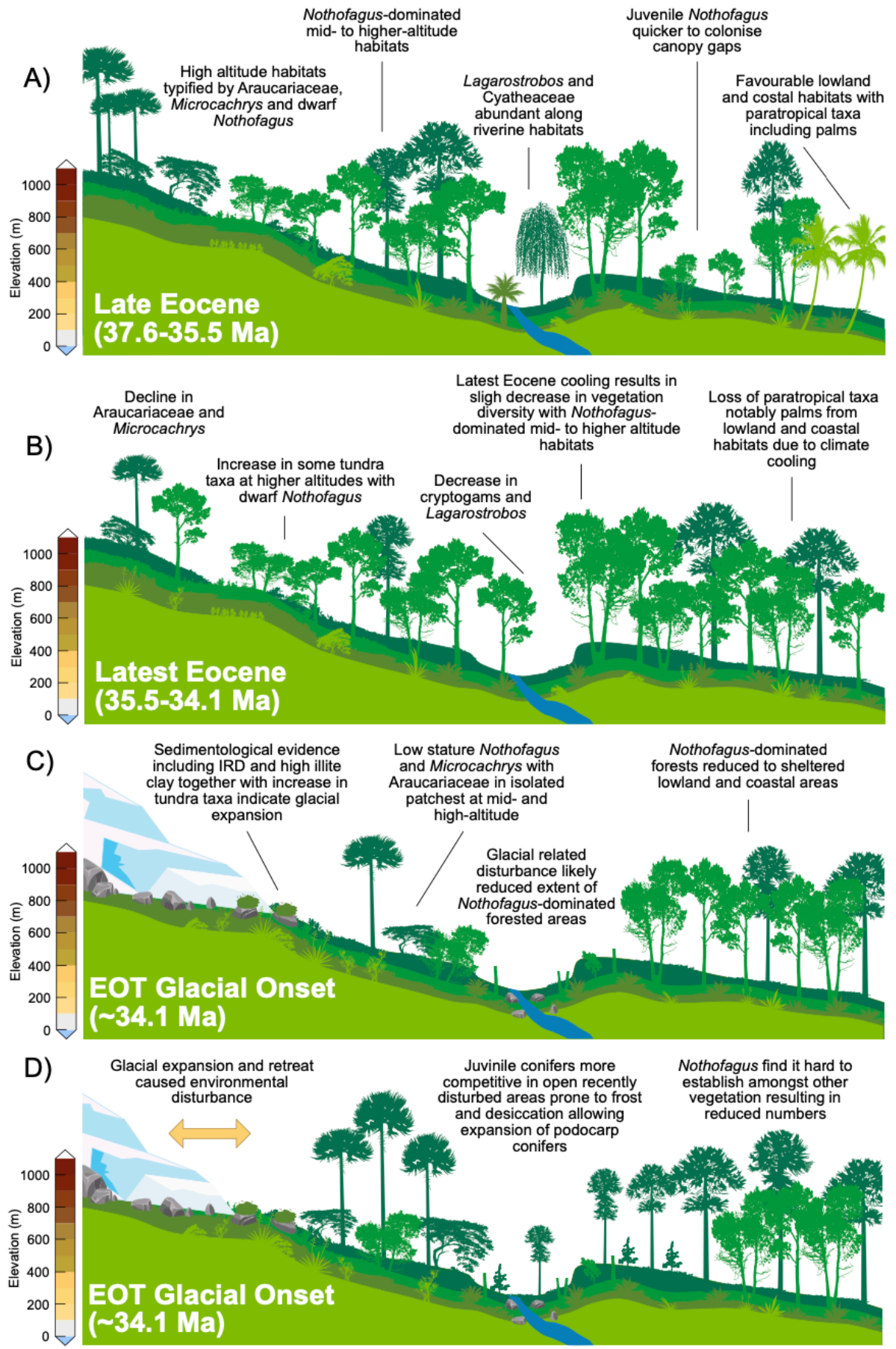

Gymnosperms 